Authors: HB Kruger and H Oosthuizen

SOUTH AFRICA - SAFE HAVEN FOR HUMAN TRAFFICKERS?

EMPLOYING THE ARSENAL OF EXISTING LAW TO COMBAT HUMAN

TRAFFICKING

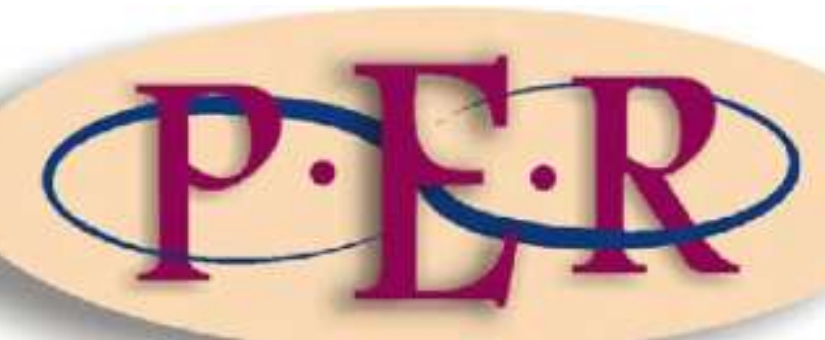

2012 VOLUME 15 No 1

http://dx.doi.org/10.4314/peli.v15i1.9 


\section{SOUTH AFRICA - SAFE HAVEN FOR HUMAN TRAFFICKERS? \\ EMPLOYING THE ARSENAL OF EXISTING LAW TO COMBAT HUMAN \\ TRAFFICKING}

\section{HB Kruger ${ }^{*}$}

H Oosthuizen

\section{Introduction}

South Africa has ratified the Protocol to Prevent, Suppress and Punish Trafficking in Persons, Especially Women and Children (the Palermo Protocol) ${ }^{1}$ and is therefore obliged to adopt legislative measures that criminalise human trafficking and comply with other standards laid down in this international instrument. By mid-2011 South Africa had not enacted the required, comprehensive counter-trafficking legislation. According to the 2011 United States Trafficking in Persons Report,

... the lack of comprehensive law that fully defines trafficking, empowers police and prosecutors ... is the greatest hindrance to anti-trafficking efforts in South Africa. ${ }^{2}$

Therefore, it is argued, traffickers continue trading in people with impunity, while law enforcement officials find their "hands tied" in endeavouring to arrest and bring these perpetrators to book. ${ }^{3}$

Recently, however, proficient prosecutors have addressed this situation by securing significant convictions in a number of trafficking cases. ${ }^{4}$ Pending the finalisation of

Hester B Kruger. BA, LLB, LLM, LLD (UFS). Senior Lecturer, Department of Criminal and Medical Law, University of the Free State, Bloemfontein, South Africa. Email: KrugerH@ufs.ac.za. This paper is partly derived from a thesis submitted in fulfillment of LLD studies.

** Hennie Oosthuizen. Bluris, LLB, LLD, LLD (UFS). Professor and Head of the Department of Criminal and Medical Law, University of the Free State, Bloemfontein, South Africa. Email: Oosthuh@ufs.ac.za.

1 Article 1-20 Protocol to Prevent, Suppress and Punish Trafficking in Persons, Especially Women and Children (Palermo Protocol) (2000).

2 US Department of State 2011 www.state.gov 328.

3 Kamidi Legal Response to Child Trafficking 46.

$4 \quad S$ v Dos Santos (unreported case; 19 July 2011, Pretoria Regional Court) (accused convicted in terms of the Criminal Law [Sexual Offences and Related Matters] Amendment Act 32 of 2007 and sentenced to life imprisonment) - SAPA 2011 www.news24.com 1; $S$ v Sayed (unreported case no. 041/2713/2008; 18 March 2010, Durban Regional Court). In 2010, the National 
the Prevention and Combating of Trafficking in Persons Bill B7 of 2010 (the 2010 Trafficking Bill), the prosecution made use of existing legal provisions to bring trafficking agents to book. ${ }^{5}$

Against this background the present article examines the utilisation of existing definitions of crimes in order to prosecute and punish criminal activities committed during the human trafficking process. First, a selection of existing common law and statutory crimes that may often be applicable to trafficking-related activities is mapped out. Second, transitional trafficking provisions in the Children's Act 38 of 2005 (Children's Act) and the Criminal Law (Sexual Offences and Related Matters) Amendment Act 32 of 2007 (Sexual Offences Amendment Act) are discussed. Finally, since the 2010 Trafficking Bill will in all probability be enacted in the near future, the use of other criminal law provisions in human trafficking prosecutions, even after the passing of this bill into law, is reflected upon. Against this background, one is tempted to say: "Traffickers, come to South Africa! Enjoy the unhindered trade in human beings - generate huge profits while the risk of being prosecuted is minimal."

\section{The existing South African criminal law framework}

It is widely acknowledged that various crimes are often committed during the trafficking process:

Human trafficking is in fact better understood as a collection of crimes bundled together rather than a single offence; a criminal process rather than a criminal event. $^{6}$

Prosecuting Authority also reported to the Justice and Constitutional Development Portfolio Committee on convictions for human trafficking activities in the following cases: $S v$ Sawatkan (unreported case no. 41/2045/08, Durban) (accused convicted in terms of the Sexual Offences Act 23 of 1957); $S$ v Wiphatawaithaya (unreported case no. 317/2/09, Durban) (accused convicted in terms of the Sexual Offences Act 23 of 1957); and S v Eloff (unreported case no. SH599/08, Welkom) (accused convicted in terms of the Criminal Law [Sexual Offences and Related Matters] Amendment Act 32 of 2007) - NPA 2010a www.pmg.org.za 3-6; NPA 2010b www.pmg.org.za 12; NPA 2010c www.pmg.org.za 3-61.

5 NPA 2010a www.pmg.org.za 3-6; NPA 2010b www.pmg.org.za 12; NPA 2010c www.pmg.org.za 3-61.

6 UNODC Toolkit xx; Bales Global Slavery 133. 
Thus, pending the enactment of counter-trafficking legislation, existing common law crimes and statutory offences may be and should be utilised to prosecute criminal conduct committed during the trafficking process. ${ }^{7}$ The successful prosecution of trafficking agents in terms of these existing crimes and offences will depend on the facts of the particular case.

\subsection{Common law crimes}

There is no common law provision dealing specifically with contemporary human trafficking. ${ }^{8}$ Still, numerous common law crimes, such as the selection discussed below, may be used to prosecute trafficking agents. ${ }^{9}$

\subsubsection{Abduction}

A perpetrator who traffics a minor to be exploited for the purpose of sexual intercourse or a forced marriage may in certain circumstances be convicted of the common law crime of abduction. ${ }^{10}$ A prosecution on a charge of abduction will be successful where such a perpetrator unlawfully and intentionally removes an unmarried minor from the control of his or her parents or guardian without their consent. ${ }^{11}$ The intention of the perpetrator in taking the minor must be that he or she, or even somebody else wishes to marry or to have sexual intercourse with the minor. ${ }^{12}$ It is important to note that, since this crime punishes a wrong committed

7 Mnisi "Trafficking in Persons" 2.

8 Mnisi "Trafficking in Persons" 2; Kassan "Trafficking in Children" 18-10; SALRC 2008 www.justice.gov.za 14; SOCA Unit 2009 www.info.gov.za 2.

9 IOM Counter-trafficking 90; Smith "South Africa's Strategy" 5; Mnisi "Trafficking in Persons" 2426.

10 Statutory versions of the common law crime of abduction were introduced into our law also by $\mathrm{s}$ 12 and 13 of the Sexual Offences Act 23 of 1957. For a discussion of these statutory crimes and how they differ from their common law counterpart, see Milton Common Law Crimes 567-572. The statutory forms of abduction do not replace common law abduction and also do not substantially differ from it - Burchell Criminal Law 764. The abduction offences in ss 12(2) and 13 of the Sexual Offences Act 23 of 1957 were repealed in 2007 by the Criminal Law [Sexual Offences and Related Matters] Amendment Act 32 of 2007 - see the schedule to this act.

11 Snyman Criminal Law 403; Milton Common Law Crimes 554. Burchell defines the crime as the unlawful taking of a minor out of the control of a custodian with the intention of enabling someone to marry or to have sexual intercourse with that minor - Burchell Criminal Law 762; Hunt Common Law Crimes 541.

12 Hunt Common Law Crimes 548-549; Snyman Criminal Law 403. Proof of the intention to marry or to have intercourse with the minor suffices. Thus, proof that the marriage or intercourse took place is not required - Snyman Criminal Law 405. For a discussion of the difference between seduction and abduction and other aspects of this crime, see Snyman Criminal Law 403-407; 
against the custodian of the minor and not against the minor, the consent of the minor to the acts of the perpetrator is no defence. ${ }^{13}$

Whether or not the ukuthwala cultural custom, which is still practised in some Nguni communities in South Africa, may be prosecuted under the crime of abduction is the subject of debate, as is whether or not such a custom constitutes human trafficking for sexual exploitation. One point of view is that the tradition of ukuthwala is indeed a forced marriage of young girls to adult men. ${ }^{14}$ However, in interpreting the ukuthwala custom within the South African context, a number of authors hold a different view. Mwambene and Sloth-Nielsen, for instance, point out that ukuthwala is not a marriage in itself, but a preliminary procedure that is employed in order to compel the family of the future bride to enter into negotiations for the conclusion of a customary marriage. ${ }^{15}$ Koyana and Bekker ${ }^{16}$ describe the custom as a means of commencing marriage negotiations by way of a "mock abduction". ${ }^{17}$ The bride-to-be is seemingly taken "by force" and kept at the residence of the future bridegroom's father pending the marriage negotiations. ${ }^{18}$

It is important to clarify whether ukuthwala constitutes the crime of abduction. Mwambene and Sloth-Nielsen maintain that South African customary law recognises those forms of ukuthwala where the future bride consents to the ukuthwala process as a legitimate means of marriage negotiation. ${ }^{19}$ This argument is also supported by the relevant provision of the Constitution of the Republic of South Africa, 1996 (1996 Constitution), which safeguards the right to participate in the cultural life of one's

Burchell Criminal Law 762-767; Milton Common Law Crimes 553-572; Hunt Common Law Crimes 537-554.

13 Snyman Criminal Law 404; Burchell Criminal Law 764-765; Milton Common Law Crimes 554555. If the minor did not consent to the taking, the perpetrator may also be convicted of kidnapping - Snyman Criminal Law 404; Hunt Common Law Crimes 546-547.

14 US Department of State 2011 www.state.gov 327.

15 Mwambene and Sloth-Nielsen 2011 African Human Rights Law Journal 1, 3, 6.

16 Koyana and Bekker 2007 De Jure 139; Olivier et al Indigenous Law 9; Burchell Criminal Law 763; McQuoid-Mason 2009 Obiter 716.

17 Koyana and Bekker 2007 De Jure 139; Olivier et al Indigenous Law 9; Burchell Criminal Law 3; McQuoid-Mason 2009 Obiter 716.

18 Olivier et al Indigenous Law 9; Mwambene and Sloth-Nielsen 2011 African Human Rights Law Journal 3. For a further discussion of the three forms of ukuthwala, see Olivier et al Indigenous Law 9-10.

19 Mwambene and Sloth-Nielsen 2011 African Human Rights Law Journal 22; see also Koyana and Bekker 2007 De Jure 141-142; Burchell Criminal Law 767. 
choice. $^{20}$ On the other hand, this right may not be not exercised in a manner inconsistent with any provision of the Bill of Rights. ${ }^{21}$ Therefore, in circumstances where the ukuthwala tradition is abused to force an unwilling girl into marriage, the courts have viewed such conduct as criminal abduction. ${ }^{22}$ Recently, reports received have indicated that young girls have been abducted under the charade of this tradition and have subsequently been forced into marrying adult men. ${ }^{23}$ Such an abuse of this tradition, where unmarried minors are removed from the control of their parents without their (the parents') consent may be successfully prosecuted on a criminal charge of abduction. ${ }^{24}$ Further, it can be argued that the misuse of the ukuthwala tradition to force girls and women into unwanted marriages may also constitute human trafficking for the purposes of sexual exploitation.

\subsubsection{Kidnapping}

Kidnapping is one of the means used to "recruit" persons for human trafficking. ${ }^{25}$ According to Snyman, kidnapping consists in

unlawfully and intentionally depriving a person of his or her freedom of movement and/or if such person is a child, the custodians of their control over the child. ${ }^{26}$

However, unlike kidnapping, human trafficking further requires that the perpetrator traffic a person with an exploitative purpose. ${ }^{27}$ Whereas kidnapping focuses mainly on the violation of the right to freedom of movement, human trafficking more often than not includes the violation of several other human rights, such as the right to the

20 Section 31(1) Constitution of the Republic of South Africa, 1996.

21 Section 31(2) Constitution of the Republic of South Africa, 1996; see also McQuoid-Mason 2009 Obiter 717.

22 Burchell Criminal Law 764; Koyana and Bekker 2007 De Jure 142; McQuoid-Mason 2009 Obiter 716-717.

23 McQuoid-Mason 2009 Obiter 716; US Department of State 2009 www.state.gov 260; US Department of State 2010 www.state.gov 297.

24 Burchell Criminal Law 764.

25 SALRC 2008 www.justice.gov.za 14; Kruger 2010 Combating Human Trafficking 422.

26 Snyman Criminal Law 479. Other writers state that kidnapping consists in unlawfully and intentionally depriving a person of liberty of movement and/or his or her custodians of control Burchell Criminal Law 758; Milton Common Law Crimes 539-541; Hunt Common Law Crimes 470.

27 Article 3(a) Palermo Protocol; see also Rijken Trafficking in Persons 65; Snyman Criminal Law 479-481; Kruger Combating Human Trafficking 51-53. 
dignity, life and security of the person. Accordingly, Stuurman ${ }^{28}$ rightly points out that the crime of trafficking in persons, as defined in the Palermo Protocol, is significantly broader than the common law crime of kidnapping. For this reason, the crime of kidnapping is too narrow to deal with trafficking cases adequately, and more comprehensive definitions of trafficking crimes must therefore be established.

In cases where adequate evidence to prove the human trafficking offence is lacking, or where applicable human trafficking legislation has not yet been enacted, prosecution on a crime of kidnapping may be successful. This crime protects two interests, namely personal freedom of movement as well as parental control over minors. ${ }^{29}$ These interests are often violated in human trafficking cases. Custodians may be deprived of control over their minor children by traffickers who take and traffic their children without the custodians' consent. Since it is the custodian's interest that is violated, the child's consent does not legalise the perpetrator's conduct. ${ }^{30}$ Perpetrators may be convicted of kidnapping also where they violate a trafficked person's freedom of movement by either physically moving the trafficked person, using force or deception, to another place or by keeping the victim locked up. $^{31}$

\subsubsection{Murder and attempted murder}

A perpetrator who causes the death of a trafficked person may be charged with murder. ${ }^{32}$ In cases where traffickers or their clients, while knowing that they are HIVpositive ${ }^{33}$ rape a trafficked person, they may be convicted of attempted murder. Such a conviction is possible, irrespective of whether or not the victim is infected with

28 Stuurman 2004 Eye on Human Trafficking 5.

29 Snyman Criminal Law 481. For a further discussion of the elements of this crime, see Milton Common Law Crimes 544-548; Hunt Common Law Crimes 470-475.

30 Burchell Criminal Law 760; Hunt Common Law Crimes 473.

31 SALRC 2008 www.justice.gov.za 14; see also Stuurman 2004 Eye on Human Trafficking 5; Snyman Criminal Law 481; Burchell Criminal Law 760; Hunt Common Law Crimes 471-473.

32 Kruger Combating Human Trafficking 423. Murder is defined as "the unlawful and intentional causing of the death of another human being" - Snyman Criminal Law 447. For a further discussion of this crime, see Burchell Criminal Law 667-671; Milton Common Law Crimes 309359; Hunt Common Law Crimes 323-368.

33 The abbreviation "HIV" is commonly used to refer to the human immunodeficiency virus. 
the human immunodeficiency virus (HIV) as a result of being raped. ${ }^{34}$ Furthermore, where evidence is presented that the victim died of acquired immune deficiency syndrome (AIDS) ${ }^{35}$ contracted as a direct result of being raped by the perpetrator, a conviction of murder can be secured. ${ }^{36}$

\subsubsection{Culpable homicide}

In some trafficking cases victims die not because the perpetrators have the intent to kill them but because their deaths are caused by the perpetrators' negligent conduct. Such cases of unlawfully and negligently causing the death of another human being can be prosecuted on a charge of culpable homicide. ${ }^{37}$ For example, where the trafficking agents force their victims to be transported in a closed container on a truck, as a result of which they die owing to a lack of oxygen, the perpetrators may be prosecuted for the crime of culpable homicide.

\subsubsection{Common assault}

Briefly stated, a perpetrator can be convicted of assault where his or her conduct results in the impairment of another's bodily integrity. ${ }^{38}$ This result can be caused in two distinct ways, namely by applying force or by inspiring the belief that force is imminently to be applied to the victim. ${ }^{39}$ Traffickers typically subject their victims to various forms of physical abuse in order to control them and force them to submit to

34 In S v Nyalungu $2005 \mathrm{JOL} 13254 \mathrm{~T}$, an HIV-positive accused was, in addition to being convicted on a charge of rape, convicted of attempted murder for raping the complainant while knowing full well that he was HIV-positive; see also SALRC 2008 www.justice.gov.za 16.

35 Infectious diseases such as AIDS are common among persons trafficked for sexual exploitation UNODC Toolkit 154; US Department of State 2008 www.state.gov 32, 34; US Department of State 2007 www.state.gov 28; Melvin Human Trafficking 28; Gajic-Veljanoski and Stewart 2007 Trans-cultural Psychiatry 346; Harrold 2006 Charleston Law Review 101; Zimmerman et al 2006 www.Ishtm.ac.uk 15.

36 SALRC 2008 www.justice.gov.za 16.

37 Burchell defines this crime as the unlawful, negligent killing of another human being - Burchell Criminal Law 674; see also Snyman Criminal Law 451; Milton Common Law Crimes 363-401; Hunt Common Law Crimes 373.

38 Snyman Criminal Law 460.

39 Milton Common Law Crimes 406-408, 420-428; SALRC 2008 www.justice.gov.za 15. Common assault is defined as "any unlawful and intentional act or omission (a) which results in another person's bodily integrity being directly or indirectly impaired, or (b) which inspires a belief in another person that such impairment of her bodily integrity is immediately to take place". Snyman Criminal Law 455; Hunt Common Law Crimes 429. 
their demands. ${ }^{40}$ These perpetrators may therefore be prosecuted for assault where they unlawfully and intentionally use their own body or an instrument to apply force directly to the person of the victim, for example by punching or kicking the victim. ${ }^{41}$ Traffickers are also known to force trafficked victims to consume alcohol and drugs to make them compliant and dependent on the trafficker. ${ }^{42}$ With reference to case law, Snyman ${ }^{43}$ and Hunt ${ }^{44}$ confirm that this indirect application of force also constitutes the crime of assault.

Apart from the direct or indirect application of force, assault is committed also where the perpetrator's conduct inspires a belief in the trafficked person that force is immediately to be applied to him or her. ${ }^{45}$ An example of this form of assault occurs when the perpetrator threatens to shoot trafficked persons should they dare to escape. $^{46}$

\subsubsection{Assault with intent to cause grievous bodily harm}

Assault with intent to cause grievous bodily harm is a form of assault qualified by a certain intention, but it is still a separate, substantive crime. ${ }^{47}$ Unlike the crime of assault, a conviction for assault with intent to cause grievous bodily harm requires that the state must prove that the perpetrator actually had the intent to cause grievous bodily harm to the victim. ${ }^{48}$ Based on case law, Snyman points out specific factors which may indicate such intent, namely

40 SALRC 2008 www.justice.gov.za 15; see also Zimmerman et al 2006 www.Ishtm.ac.uk 2, 10, 1314, 22; Gajic-Veljanoski and Stewart 2007 Trans-cultural Psychiatry 345; Kreston 2007 Child Abuse Research in South Africa 39; IOM Breaking the Cycle 14.

41 Burchell Criminal Law 684; Snyman Criminal Law 456.

42 US Department of State 2007 www.state.gov 28; Haynes 2004 Hum Rts Q 226; Gajic-Veljanoski and Stewart 2007 Trans-cultural Psychiatry 341.

43 Snyman Criminal Law 457. In contrast, Lansdown, by way of a single reference to $R v$ Hanson 18492 C \& K 912, submits that to administer poison with the intent to harm a person does not constitute assault - Lansdown, Hoal and Lansdown Specific Offences 1572.

44 Hunt Common Law Crimes 437.

45 Burchell Criminal Law 680, 686; Snyman Criminal Law 458; Milton Common Law Crimes 422428; Hunt Common Law Crimes 438-445.

46 Burchell Criminal Law 687.

47 Hunt Common Law Crimes 450; Snyman Criminal Law 461.

48 Snyman Criminal Law 461-462; Burchell Criminal Law 688-691; Hunt Common Law Crimes 451453. 
the nature of the weapon or instrument used, the way in which it was used, the degree of violence, the part of the body aimed at, the persistence of the attack, and the nature of the injuries inflicted, if any. ${ }^{49}$

It is important to note that it is not required that the perpetrator actually cause grievous bodily harm. ${ }^{50}$ It suffices if the intent to cause such harm is proven, even where only a slight injury or no injury at all is caused, for instance where the trafficker shoots at the victim but misses. ${ }^{51}$ The fact that serious and continuous assaults are usually inflicted on trafficked persons ${ }^{52}$ justifies prosecution for assault with the intent to cause grievous bodily harm in many human trafficking cases.

\subsubsection{Extortion}

The crime of extortion is committed where a person

unlawfully and intentionally obtains some advantage, which may be of either a patrimonial or a non-patrimonial nature, from another by subjecting the latter to pressure, which induces her to hand over the advantage. ${ }^{53}$

Traffickers often use such unlawful pressure in the form of threats or intimidation to compel unwilling trafficked victims to submit to their demands. ${ }^{54}$ For example, perpetrators may threaten victims with physical harm or reprisal against their families in order to obtain an advantage, such as the provision of services not legally due to the perpetrator. ${ }^{55}$ Also, where trafficked victims are forced into crime or exploitative sexual activities some are threatened that photos or video recordings of such

49 Snyman Criminal Law 462; see also SALRC 2008 www.justice.gov.za 15; Burchell Criminal Law 689-690; Hunt Common Law Crimes 452-453. For a discussion of the case law on factors indicating the intent to do grievous bodily harm, see Snyman Criminal Law 462, especially fn 40 42.

50 Burchell Criminal Law 690; Hunt Common Law Crimes 451.

51 SALRC 2008 www.justice.gov.za 14, 16.

52 Zimmerman et al 2006 www.Ishtm.ac.uk 2, 10, 13-14, 22; Gajic-Veljanoski and Stewart 2007 Trans-cultural Psychiatry 345; Kreston 2007 Child Abuse Research in South Africa 39; IOM Breaking the Cycle 14.

53 Snyman Criminal Law 426; see also Burchell Criminal Law 826-832; Milton Common Law Crimes 681-697; Hunt Common Law Crimes 652.

54 Defeis 2003/2004 ILSA J Int'I \& Comp L 488; Foundation against Trafficking in Women et al Human Rights Standards 6; SALRC 2008 www.justice.gov.za 17; IOM Training of Trainers 30; Dougherty and Burke 2008 America 12; Brennan 2005 International Migration 42; GajicVeljanoski and Stewart 2007 Trans-cultural Psychiatry 344; Morawska "Trafficking" 94; Shelley "Human Trafficking" 131; Weissbrodt and Anti-slavery International Abolishing Slavery 31-32; Dottridge and Weissbrodt 1999 German Yearbook of International Law 270.

55 SALRC 2008 www.justice.gov.za 17. 
conduct will be disclosed to their families or to law enforcement authorities. ${ }^{56}$ The advantage that traffickers obtain by exerting this unlawful pressure is to exploit the victim further to their benefit. ${ }^{57}$ In these circumstances, prosecution for the crime of extortion is apposite.

However, the prosecution faces a problem where the extortion has taken place outside the borders of South Africa. In such cases, as with kidnapping committed outside South Africa, it is not possible to prosecute perpetrators for these common law crimes. $^{58}$ Comprehensive counter-trafficking legislation which provides for extraterritorial jurisdiction is required to address this problem. ${ }^{59}$

\subsubsection{Crimen iniuria}

According to Burchell, crimen iniuria consists in the unlawful and intentional "impairing [of] the dignity or privacy of another person". ${ }^{60}$ A person's dignity may be impaired in countless ways, ${ }^{61}$ which makes this crime applicable in many if not most trafficking cases. A conviction may follow where a trafficker violates a victim's dignity by using vulgar and abusive language or conduct, such as spitting in the victim's face. $^{62}$ A victim's sexual dignity may be impaired by explicit conduct such as unwanted kissing, the touching of private parts ${ }^{63}$ or forced participation in other sexual acts. ${ }^{64}$ At the beginning of the trafficking process traffickers often pretend to be the victim's friend or lover. Frequently, they do this by communicating via cellphone or Internet chatrooms, the purpose being to persuade the victim gradually

56 SALRC 2008 www.justice.gov.za 17. Burchell views such threats to disclose embarrassing information as a form of pressure to obtain an advantage which is not legally due to the perpetrator - Burchell Criminal Law 829.

57 The advantage that is being extorted need not be only of a patrimonial nature; other advantages such as sexual gratification also qualify - Burchell Criminal Law 831; Hunt Common Law Crimes 653; see also s 1 of the General Law Amendment Act 139 of 1992.

58 SALRC 2008 www.justice.gov.za 17.

59 See the discussion on extraterritorial jurisdiction in Kruger Combating Human Trafficking 336338.

60 Burchell Criminal Law 746; see also Snyman Criminal Law 469; Milton Common Law Crimes 492; Hunt Common Law Crimes 486.

61 Burchell Criminal Law 749-753.

62 Hunt Common Law Crimes 503-504.

63 Hunt Common Law Crimes 501. Sexual abuse of the victim by the trafficker can also be punished as rape, compelled rape, sexual assault, and so forth, in terms of the Criminal Law (Sexual Offences and Related Matters) Amendment Act 32 of 2007.

64 Snyman Criminal Law 472-473. 
to submit to sexual acts. ${ }^{65}$ The use of this modern form of sexual "grooming" constitutes behaviour that impairs dignity; hence such perpetrators may be prosecuted for crimen iniuria. ${ }^{66}$ Furthermore, a trafficker may also be convicted of this crime for violations of privacy, such as voyeuristic peeping, ${ }^{67}$ eavesdropping, ${ }^{68}$ electronic surveillance ${ }^{69}$ and reading private communications such as letters, cellphone messages or e-mails.

\subsubsection{Criminal defamation}

Criminal defamation differs from crimen iniuria in that it criminalises "the unlawful and intentional publication of matter concerning another which tends seriously to injure his reputation". 70

This criminalisation of such publication protects a person's fama (good name or reputation) from defamatory conduct which tends to expose a victim to hatred or ridicule, thus diminishing the esteem in which the victim is held by others. ${ }^{71}$ The required "publication" of the defamatory conduct is interpreted to mean that the defamatory conduct of the perpetrator must come to the notice of someone other than the complainant. ${ }^{72}$ Therefore, traffickers may be charged with this crime when they provide information in order to injure the reputation of victims, for example by informing victims' families or employers that they perform sexual services, are

65 US Department of State 2008 www.state.gov 13; US Department of State 2007 www.state.gov 23; Weissbrodt and Anti-slavery International Abolishing Slavery 34-35; Dottridge and Weissbrodt 1999 German Yearbook of International Law 266; Hodgkin and Newell Implementation Handbook 527; Raymond 2002 Women's International Forum 492; GAATW Human Rights in Practice 13. The sexual "grooming" of potential victims involves those acts of a perpetrator, such as providing luxurious gifts and outings, that are aimed at facilitating the commission of an illegal sexual act with another person - Burchell Criminal Law 750.

66 Burchell Criminal Law 750.

67 Milton Common Law Crimes 513-514; Burchell Criminal Law 753; R v Holliday 1927 CPD 395.

68 Milton Common Law Crimes 514.

69 Examples of such surveillance are e-mail or telephone tapping and unauthorised accessing (also known as "hacking" - Buys and Cronjé Cyberlaw 320, 327) of electronic data - Burchell Criminal Law 753.

70 Snyman Criminal Law 475; Milton Common Law Crimes 520; Hunt Common Law Crimes 518.

71 Snyman Criminal Law 476. For a further discussion of this crime, see Milton Common Law Crimes 524-535; Hunt Common Law Crimes 518-530.

72 Milton Common Law Crimes 533; Snyman Criminal Law 476; Burchell Criminal Law 744; Hunt Common Law Crimes 527. 
thieves, are drug couriers or are participants in pornography, while not disclosing that they (the victims) have been coerced or deceived into these situations. ${ }^{73}$

\subsubsection{Fraud and related crimes}

A typical recruitment method used to lure persons into the trafficking trap is deception. ${ }^{74}$ Raymond points out that the vast majority of victims are being trafficked through false promises or other forms of deception and not by forceful methods such as kidnapping or abduction. ${ }^{75}$ The literature indicates that deceptive methods used to recruit potential trafficking victims vary, but most often include the promise of lucrative job or educational opportunities. ${ }^{76}$

The well-known crime of fraud may be used to prosecute trafficking offenders for misrepresentations made to trafficked persons. Misrepresentation, which constitutes the conduct element of fraud, entails deceiving someone by means of a falsehood, or, as Snyman explains it, is the situation where one person represents to another that "a fact or a set of facts exists which in truth does not exist". ${ }^{77}$ A trafficker who unlawfully and intentionally makes a misrepresentation to a trafficked person, which then causes the latter actual prejudice or even potential prejudice, may be convicted of fraud. ${ }^{78}$ Species of fraud, namely forgery and uttering, which entail the forging of a document or presenting such a forged document as a genuine document to another, may also find application in trafficking cases. ${ }^{79}$ For example, when trafficking agents forge passports or other travel documents, or present such forged documents to

73 Molo Songololo Trafficking in Children vi.

74 UN.GIFT "Profiling the Traffickers" 12; IOM Breaking the Cycle 20; IOM Training of Trainers 22; Gajic-Veljanoski and Stewart 2007 Trans-cultural Psychiatry 342; Shelley "Human Trafficking" 128.

75 Raymond 2002 Women's International Forum 497.

76 UN.GIFT "Profiling the Traffickers" 12; IOM Breaking the Cycle 20; IOM Training of Trainers 22, 25; Gajic-Veljanoski and Stewart 2007 Trans-cultural Psychiatry 342-343; Shelley "Human Trafficking" 128; Raymond 2002 Women's International Forum 497; Singh 2004 CILSA 341; Weissbrodt and Anti-slavery International Abolishing Slavery 22; UNODC 2009 www.unodc.org 12-13; Rijken Trafficking in Persons 63; Foundation against Trafficking in Women et al Human Rights Standards 6; US Department of State 2009 www.state.gov 8; US Department of State 2007 www.state.gov 10; The Future Group 2007 tfgwebmaster.web.aplu.net 2.

77 Snyman Criminal Law 532.

78 For a discussion of the definitional elements of fraud, see Snyman Criminal Law 531-540; Burchell Criminal Law 833-844.

79 For a discussion of the definitional elements of forgery and uttering, see Snyman Criminal Law 540-543; Burchell Criminal Law 845-848. 
government officials as valid documents, a prosecution on a charge of forgery or uttering, or both crimes, may be instituted against the offenders.

\subsubsection{Slavery}

Picarelli and others refer to human trafficking as a modern manifestation of slavery or modern-day slavery. ${ }^{80}$ It is thus appropriate to clarify whether or not slavery is recognised as an existing common law crime in South African law which could be used to prosecute certain criminal activities related to human trafficking.

The Constitution of the Republic of South Africa, 1996 provides a normative framework concerning slavery by stipulating that no-one may be subjected to slavery, servitude or forced labour. ${ }^{81}$ However, enshrining this human right does not in itself create the crime of slavery in South African law.

The literature concurs that slavery is recognised as an international crime in international customary law. ${ }^{82}$ The fact that slavery qualifies as an international crime gives all states the right to prosecute slavery, because international crimes violate not only the domestic legal order of a state, but also the international order. ${ }^{83}$ In other words, national courts may exercise jurisdiction over international crimes, acting "as the agent of the international community in the prosecution of an enemy of all mankind". 84

80 Picarelli "Historical Approaches" 26; US Department of State 2007 www.state.gov 8; US Department of State 2008 www.state.gov 1; Dottridge and Weissbrodt 1999 German Yearbook of International Law 260; Nowak Civil and Political Rights 195; Weissbrodt and Anti-slavery International Abolishing Slavery 19.

81 Section 13 Constitution of the Republic of South Africa, 1996.

82 Viljoen Human Rights Law 26-27; Weissbrodt and Anti-slavery International Abolishing Slavery 3; Dottridge and Weissbrodt 1999 German Yearbook of International Law 243-244; SALRC 2008 www.justice.gov.za 17; Bassiouni International Crimes 419-420; Bassiouni 1990/1991 NYUJ Int'I L \& Pol 447; Kruger Combating Human Trafficking 168-170. For a comprehensive analysis of enslavement as an international crime, see Bassiouni 1990/1991 NYUJ Int'l L \& Pol 445-491. Dugard provides a further discussion of customary international law as the common law of the international community - Dugard International Law 29-33.

83 Dugard International Law 156-157; SALRC 2008 www.justice.gov.za 17.

84 Dugard International Law 156. 
In addition, slavery has attained the status of ius cogens, which consists of peremptory norms in international law in respect of which no derogation is permitted. ${ }^{85}$

Having clarified the position of slavery in international customary law, it now needs to be determined if international customary law recognising slavery as an international crime finds application in South African law. Dugard ${ }^{86}$ points out that the South African courts follow the monist approach ${ }^{87}$ of incorporating international customary law into the common law of South Africa. Underpinning this point, the 1996 Constitution confirms that "customary international law is law in the Republic, unless it is inconsistent with the Constitution or an act of Parliament". ${ }^{88}$

Against this background Dugard ${ }^{89}$ concludes that slavery is an international crime which is incorporated in the law of South Africa.

Despite the conclusion that slavery is a common law crime in South African law, current South African criminal law textbooks do not include slavery when dealing with South African common law crimes. ${ }^{90}$ Also, no reported case of a successful prosecution for such a crime could be traced. Nevertheless, neither the legislature nor a court of law has determined that the crime of slavery has fallen into desuetude. ${ }^{91}$ It can therefore be argued that the crime of slavery, as recognised in

85 Dugard International Law 43-44; Bales and Robbins 2001 Human Rights Review 19; Viljoen Human Rights Law 27-28; Devenish Constitution 77; Brownlie Public International Law 488-489; Weissbrodt and Anti-slavery International Abolishing Slavery 3; Rijken Trafficking in Persons 74; Dottridge and Weissbrodt 1999 German Yearbook of International Law 243; Nowak Civil and Political Rights 197. For a discussion of the concept ius cogens in international law, see Dugard International Law 43-46.

86 Dugard International Law 51-52; SALRC 2008 www.justice.gov.za 17.

87 The monist approach maintains that international law may be directly applied by domestic courts without an act of adoption by the courts or transformation of international law into local law by legislation - Dugard International Law 47.

88 Section 232 Constitution of the Republic of South Africa, 1996; see also SALRC 2008 www.justice.gov.za 17.

89 Dugard International Law 160.

90 Snyman Criminal Law 401-482, Burchell Criminal Law 661-908, Milton Common Law Crimes 1817 and Hunt Common Law Crimes 1-785 do not include the common law crime of slavery in their criminal law textbooks - see also SALRC 2008 www.justice.gov.za 17.

91 SALRC 2008 www.justice.gov.za 17. Although a statute cannot be abolished by disuse, our courts may rule that a part of common law or customary law has become abrogated by disuse. For example, in Green v Fitzgerald 1914 AD 88, the court found that the rule that adultery is a crime had been abolished by disuse - Kleyn and Viljoen Beginner's Guide 83, 89; see also Du Plessis Inleiding 244-245. 
international customary law, is part of South African common law. However, whether or not the common law crime of slavery can, and should, be used in appropriate cases to prosecute perpetrators involved in human trafficking activities is uncertain and needs to be further researched.

To conclude, it is conceded that the common law crimes discussed above are not comprehensive enough to deal adequately with the complexities of human trafficking. However, common law crimes can be used in certain circumstances to prosecute some of the criminal acts committed during the human trafficking process.

\subsection{Statutory offences}

Apart from common law crimes, the use of a number of existing statutory offences to prosecute perpetrators involved in trafficking activities for crimes other than human trafficking may be considered. ${ }^{92}$

\subsubsection{Riotous Assemblies Act 17 of 1956}

A number of trafficking agents are often involved in a human trafficking scenario. ${ }^{93}$ The prosecution net should therefore be cast wide to include those who either conspire with others to commit a crime against a trafficked person or who incite or command others to commit a crime against such a victim. ${ }^{94}$ The Riotous Assemblies Act 17 of 1956 may be used successfully to accomplish this purpose, as well as to prosecute offenders for attempting to commit human trafficking. ${ }^{95}$

92 Smith "South Africa's Strategy" 6; Mnisi "Trafficking in Persons" 9; Kassan "Trafficking in Children" 18-10.

93 See Shelley "Human Trafficking" 118, 120; Obokata Trafficking of Human Beings 46; Raymond 2002 Women's International Forum 493; Foundation against Trafficking in Women et al Human Rights Standards 5; Singh 2004 CILSA 343; UN.GIFT "Profiling the Traffickers" 8.

94 IOM Counter-trafficking 89; SALRC 2008 www.justice.gov.za 20.

95 Section 18(2) Riotous Assemblies Act 17 of 1956: "Any person who - (a) conspires with any other person to aid or procure the commission of or to commit; or (b) incites, instigates, commands, or procures any other person to commit any offence, whether at common law or against a statute or statutory regulation, shall be guilty of an offence and liable on conviction to the punishment to which a person convicted of actually committing that offence would be liable." 


\subsubsection{Identification Act 68 of 1997}

The Identification Act 68 of 1997 requires South African citizens and persons who are lawfully and permanently resident in the Republic of South Africa to obtain an identity card after the age of 16 years has been attained. ${ }^{96}$ Where role-players in the human trafficking team imitate or alter the identity cards of their victims, or are merely in possession of such cards, they may be successfully prosecuted in terms of this act $^{97}$ and, on conviction, be imprisoned for up to five years. ${ }^{98}$

In many cases, trafficking agents confiscate valid identity cards and travel documents of trafficked persons in order to maintain control over them. ${ }^{99}$ Prosecution for such conduct does not seem to be possible in terms of this act. ${ }^{100}$ This loophole for traffickers highlights the need for more comprehensive legislation designed to prosecute the variety of criminal acts committed by agents during the trafficking process.

\subsubsection{Immigration Act 13 of 2002}

In cases where persons are trafficked across international borders, the provisions of the Immigration Act 13 of 2002 (Immigration Act) are often violated. This act regulates entry into and departure from South Africa. ${ }^{101}$ The National Prosecuting Authority reported convictions in the cases of $S v$ Sayed ${ }^{102}$ and $S v$ Sawatkan in terms of this act for human trafficking-related activities. ${ }^{103}$

96 Section 15 Identification Act 68 of 1997; see also ss 3, 7(1) and 8.

97 Sections 18(1)(d)-(e) Identification Act 68 of 1997.

98 Section 18(2)(a) Identification Act 68 of 1997.

99 Haynes 2004 Hum Rts Q 226; US Department of State 2007 www.state.gov 20; IOM Training of Trainers 30; Melvin Human Trafficking 29; Kanics and Reiter 2001 Helsinki Monitor 112; GajicVeljanoski and Stewart 2007 Trans-cultural Psychiatry 339; Morawska "Trafficking 100"; Kruger Combating Human Trafficking 150-151.

100 Stuurman 2004 Eye on Human Trafficking 5.

101 Section 49 Immigration Act 13 of 2002; IOM Counter-trafficking 87.

102 In S v Sayed (unreported case no. 041/2713/2008, 18 March 2010, Durban Regional Court), convictions were secured in terms of s 49(6) of the Immigration Act 13 of 2002.

103 NPA 2010b www.pmg.org.za 12; NPA 2010c www.pmg.org.za 1. 
Traffickers who enter, remain in, or depart from South Africa in contravention of this act may therefore be prosecuted. ${ }^{104}$ Strikingly, the maximum term of imprisonment for this offence is only three months. ${ }^{105}$ Traffickers often assist their victims to illegally enter, remain in, or depart from a country. ${ }^{106}$ This conduct also is criminalised in the act, but the maximum term of imprisonment is also short, being only one year. ${ }^{107}$ In addition, trafficking agents who knowingly employ an illegal foreigner or a foreigner in violation of this act may on conviction also be imprisoned for up to one year only. ${ }^{108}$ For the offence of aiding and abetting foreigners, ${ }^{109}$ the penalty is a maximum of 18 months' imprisonment. ${ }^{110}$ The literature emphasises that stringent sentences are needed to deter traffickers. ${ }^{111}$ It is therefore submitted that the lenient sanctions for these offences are insufficient to dissuade offenders.

Corrupting and bribing officials for the purpose of executing the trafficking crime are often part of the modus operandi of traffickers. ${ }^{112}$ Such illegal conduct, which includes bribing or threatening officials so as to obtain a passport or to cross borders without a passport, can also be prosecuted under the Immigration Act. $^{113}$

The act further contains several provisions criminalising illegal conduct related to passports and other documents, conduct which traffickers are often guilty of. ${ }^{114}$ It has

104 Section 49(1)(a) Immigration Act 13 of 2002.

105 Section 49(1)(a) Immigration Act 13 of 2002.

106 UN.GIFT "Profiling the Traffickers" 11; Harrold 2006 Charleston Law Review 101; Melvin Human Trafficking 22; UNODC Toolkit xiv-xv; Lansink 2006 Agenda 47; Kamidi Legal Responses to Child Trafficking 10.

107 Section 49(2) Immigration Act 13 of 2002.

108 Section 49(3) Immigration Act 13 of 2002.

109 The aiding, abetting, assisting, enabling or in any manner helping of a foreigner by, for example, "entering into an agreement with him or her for the conduct of any business or the carrying on of any profession or occupation" in terms of s 42(1)(iii) of the act is criminalised. On 18 March 2010, two accused were convicted in the unreported case of $S v$ Sayed (case no. 041/2713/2008) in the Durban Regional Court on two charges of aiding and abetting foreigners in terms of $s 49(6)$ of the Immigration Act 13 of 2002. The convictions were for entering into a debt-bondage agreement in Durban with Thai women recruited in Thailand, to pay the accused R60 000 generated from prostitution activities at the brothel, whereafter the women were allowed to retain some of the profit for themselves.

110 Section 49(6) Immigration Act 13 of 2002.

111 UN.GIFT "Human Trafficking" 10; US Department of State 2011 www.state.gov 328; US Department of State 2008 www.state.gov 27; Shelley "Human Trafficking" 132; Raymond 2002 Women's International Forum 492.

112 Singh 2004 CILSA 345; Shelley "Human Trafficking" 132.

113 Section 49(10) Immigration Act 13 of 2002: "Anyone who through offers of financial or other consideration or threats, compels or induces an officer to contravene this Act or to breach such officer's duties shall be guilty of an offence." See also SALRC 2008 www.justice.gov.za 20.

114 Section 49(15) Immigration Act 13 of 2002. 
been reported that fabricated or falsified travel documents are used when traffickers themselves or their victims cannot cross international borders legally. ${ }^{115}$ The Immigration Act criminalises the use of such fabricated or falsified passports for the purpose of crossing a South African border or assisting a victim to do so. ${ }^{116} \mathrm{~A}$ further provision prohibits a person from being in possession of another person's travel or identity document or of a blank, falsified or fabricated passport. ${ }^{117}$ Notably, this provision may be used where perpetrators use false travel documents or where they hold the travel or identity documents of their victims as a tool for controlling them. ${ }^{118}$ For these offences, imprisonment of up to four years may be imposed. ${ }^{119}$ However, Stuurman points out that this act does not "... deal with related issues, such as the protection of victims of trafficking or the confiscation, or destruction, of their travel and identity documents". ${ }^{120}$

More comprehensive legislative measures are therefore needed to address these criminal acts, which are often committed during the trafficking cycle.

\subsubsection{Basic Conditions of Employment Act 75 of 1997}

In cases where people are trafficked specifically for labour exploitation, the provisions in the Basic Conditions of Employment Act 75 of 1997 (Basic Conditions of Employment Act) may find application. ${ }^{121}$ The purpose of this act is to

give effect to the right to fair labour practices referred to in section 23(1) of the Constitution by establishing and making provision for the regulation of basic conditions of employment. $^{122}$

115 Stuurman 2004 Eye on Human Trafficking 5.

116 Section 49(15)(a) Immigration Act 13 of 2002.

117 Section 49(15)(b) Immigration Act 13 of 2002.

118 Haynes 2004 Hum Rts Q 226; US Department of State 2007 www.state.gov 20; IOM Training of Trainers 30; Melvin Human Trafficking 29; Kanics and Reiter 2001 Helsinki Monitor 112; GajicVeljanoski and Stewart 2007 Trans-cultural Psychiatry 339; Morawska "Trafficking" 100; Stuurman 2004 Eye on Human Trafficking 5; UNODC 2009 www.unodc.org 21.

119 Section 49(15) Immigration Act 13 of 2002.

120 Stuurman 2004 Eye on Human Trafficking 5.

121 SOCA Unit 2009 www.info.gov.za 2.

122 See s 2 and the long title Basic Conditions of Employment Act 75 of 1997; IOM Countertrafficking 88. 
Accordingly, the act sets minimum employment standards regarding a range of labour matters, including maximum working hours, ${ }^{123}$ overtime, ${ }^{124}$ sick leave, ${ }^{125}$ meal intervals $^{126}$ and annual leave. ${ }^{127}$ Many of these provisions are commonly violated in labour trafficking cases. ${ }^{128}$

Consequently, this act may be used to prosecute perpetrators for a range of labour offences committed during the trafficking process. First, what is relevant to this article is that the act explicitly prohibits all forms of forced labour. ${ }^{129}$ Moreover, noone may for his or her own benefit or for the benefit of someone else cause, demand or impose forced labour. ${ }^{130}$ Regrettably, the maximum penalty for these offences is only three years' imprisonment, ${ }^{131}$ which is inadequate in serious cases of prolonged forced labour.

Secondly, there are also provisions in this act which specifically protect children. Section 43(1) of the act prohibits the employment of a child under the age of 15 years, ${ }^{132}$ except if a permit is obtained from the Department of Labour to employ the child in the performance of advertising, sports, artistic or cultural activities. ${ }^{133}$ As regards older children aged 15 to 18 years, it is stipulated that they may not be employed to do work inappropriate for their age or that places the child's wellbeing at risk. $^{134}$ This prohibition can, for example, be used against traffickers who traffic children for forced military service. ${ }^{135}$

123 Section 9 Basic Conditions of Employment Act 75 of 1997.

124 Section 10 Basic Conditions of Employment Act 75 of 1997.

125 Section 22 Basic Conditions of Employment Act 75 of 1997.

126 Section 14 Basic Conditions of Employment Act 75 of 1997.

127 Section 20 Basic Conditions of Employment Act 75 of 1997.

128 GAATW Human Rights in Practice 14, 16; Devenish Commentary 54; Nowak Civil and Political Rights 201.

129 Section 48(1) Basic Conditions of Employment Act 75 of 1997: "Subject to the Constitution, all forced labour is prohibited." See also SALRC 2008 www.justice.gov.za 21.

130 Section 48(2) Basic Conditions of Employment Act 75 of 1997; see also SALRC 2008 www.justice.gov.za 21.

131 Section 93(2) Basic Conditions of Employment Act 75 of 1997.

132 For a further discussion of this section, see SOCA Unit 2009 www.info.gov.za 2; Dawes, Bray and Van der Merwe Child Well-being 249, 255-258.

133 Section 50(2)(b) Basic Conditions of Employment Act 75 of 1997; Dawes, Bray and Van der Merwe Child Well-being 249.

134 Section 43(2) Basic Conditions of Employment Act 75 of 1997.

135 For a discussion of these types of exploitation, see Kruger Combating Human Trafficking 72-75. 
The concept "forced labour" is not defined in the Basic Conditions of Employment Act or in any other South African legislation. ${ }^{136}$ The definition of forced labour in the 1930 International Labour Organization Convention No. 29 Concerning Forced Labour is still internationally accepted. ${ }^{137}$ According to Devenish, ${ }^{138}$ the gist of forced labour is "work done without consent and invariably without fair and just compensation". This type of labour practice is common in human trafficking scenarios, where trafficked persons do not perform services willingly but are compelled by assaults, threats and other coercive measures to perform services without being fairly compensated for such services. ${ }^{139}$

To conclude, it is possible to prosecute trafficking agents in terms of the Basic Conditions of Employment Act for contravening the labour provisions in this act. However, the concern remains that stringent sentences are necessary in serious human trafficking cases, , whereas this act provides for a maximum term of imprisonment of only three years for contravening the provisions discussed above. ${ }^{140}$

\subsubsection{Child Care Act 74 of 1983}

Although the provisions of the Child Care Act 74 of 1983 (Child Care Act) were repealed in toto by the Children's Act 38 of 2005 on 1 April 2010, the act may still be used by the prosecution in trafficking cases occurring prior to this date. ${ }^{141}$ Aiming at the protection and welfare of children, the Child Care Act criminalised various forms of abusive behaviour towards children. As a rule, trafficked children are subjected to exploitation. Therefore, in prohibiting the ill-treatment of children this act may be used to prosecute perpetrators who exploited and ill-treated trafficked children. ${ }^{142}$ In

136 SALRC 2008 www.justice.gov.za 21.

137 This convention defines forced labour as "all work or service which is exacted from any person under the menace of any penalty and for which the said person has not offered himself voluntarily." (A 2 International Labour Organization Convention No. 29 Concerning Forced Labour (1930).

138 Devenish Commentary 54; Nowak Civil and Political Rights 201. Currie and De Waal Bill of Rights 313 endorse this view by emphasising that the key definitional feature of forced labour is involuntariness.

139 IOM Training of Trainers 24; UN.GIFT "Demand for Forced Labour" 2.

140 The maximum penalties for the contravention of the provisions in this act are set out in $s 93$ Basic Conditions of Employment Act 75 of 1997.

141 Schedule 4 to the Children's Act 38 of 2005; Kassan "Trafficking in Children" 18-10.

142 Section 50(1) Child Care Act 74 of 1983. 
addition, since the act prohibited the commercial sexual exploitation of children ${ }^{143}$ it may therefore find application in cases where children were trafficked for such exploitation.

\subsubsection{Children's Act 38 of 2005}

In line with the standard that children are entitled to special care and assistance as laid down in the 1948 Universal Declaration of Human Rights, ${ }^{144}$ the Children's Act 38 of 2005 (Children's Act) regulates the care and protection of children comprehensively. ${ }^{145}$ One of the main aims of the Children's Act is to give effect to certain rights of children as contained in the 1996 Constitution. ${ }^{146}$ The offences created in this act ${ }^{147}$ are in operation and include the criminalisation of the abuse or deliberate neglect of a child by persons with parental responsibilities as well as by others who voluntarily care for the child. ${ }^{148}$ The act defines "abuse" broadly to mean:

any form of harm or ill-treatment deliberately inflicted on a child, and includes -

(a) assaulting a child or inflicting any other form of deliberate injury to a child;

(b) sexually abusing a child or allowing a child to be sexually abused;

(c) bullying by another child;

(d) a labour practice that exploits a child; or

(e) exposing or subjecting a child to behaviour that may harm the child psychologically or emotionally. ${ }^{149}$

It has been reported that not only strangers but also parents and family members are involved in child trafficking. ${ }^{150}$ During the trafficking process children are often exposed to the ill-treatment prohibited in section 305(3) of this act, such as physical and sexual abuse, labour exploitation, and circumstances that are psychologically

143 Section 50A(1) Child Care Act 74 of 1983: "'Commercial sexual exploitation' means the procurement of a child to perform a sexual act for a financial or other reward payable to the child, the parents or guardian of the child, the procurer or any other person."

144 Section 25(2) Universal Declaration of Human Rights (1948); see also Bassiouni 1990/1991 NYUJ Int'l L \& Pol 482; Brownlie and Goodwin-Gill Human Rights 23.

145 Long title of, and preamble to, the act; Bosman-Sadie and Corrie Children's Act 2-313; Boezaart Child Law 3. For a discussion of the trafficking provisions contained in the Children's Act 38 of 2005, see 3.1 below.

146 Long title of, and preamble to, Children's Act 38 of 2005; see also Human "Theory of Children's Rights" 243-290; Bosman-Sadie and Corrie Children's Act 14-15.

147 Section 305 Children's Act 38 of 2005; Bosman-Sadie and Corrie Children's Act 303-306.

148 Section 305(3) Children's Act 38 of 2005; Minnie "Sexual Offences" 540-541.

149 Section 1 Children's Act 38 of 2005; Bosman-Sadie and Corrie Children's Act 2; Minnie "Sexual Offences" 540-541.

150 Obokata Trafficking of Human Beings 46; Raymond 2002 Women's International Forum 493; Kreston 2007 Child Abuse Research in South Africa 39; SALRC 2004 www.doj.gov.za 1. 
and emotionally harmful. ${ }^{151}$ This section can therefore be applied to persons with parental responsibilities and to caregivers who ill-treat trafficked children in their care. $^{152}$

\subsubsection{Prevention of Organised Crime Act 121 of 1998}

In short, organised crime involves the cooperation of several persons in order to commit crimes. To combat organised crime is challenging because of the effective organisation of these criminal groups and because of their criminal expertise, resourcefulness, efficient use of the latest technology, and expansion over regions and even continents. ${ }^{153}$ For this reason the criminal justice system has adopted an innovative approach aimed at eliminating the organisation and the proceeds of crime rather than punishing only the individual criminal. ${ }^{154}$ Ackerman $\mathrm{J}$ summarised this new paradigm in NDPP $v$ Mohamed as follows:

It is common cause that conventional criminal penalties are inadequate as measures of deterrence when organised crime leaders are able to retain the considerable gains derived from organised crime, even on those occasions when they are brought to justice... . [I]t is now widely accepted in the international community that criminals should be stripped of the proceeds of their crime, the purpose being to remove the incentive for crime, not to punish them. ${ }^{155}$

This approach has been adopted by the Prevention of Organised Crime Act 121 of 1998 (Prevention of Organised Crime Act). ${ }^{156}$ With the key aim of curbing the scourge of organised crime, ${ }^{157}$ the act covers various issues related to organised crime activities, such as racketeering, gang-related offences, money-laundering and asset forfeiture. ${ }^{158}$ This act criminalises organised crime activities and defines a "criminal gang" widely to include

151 IOM Breaking the Cycle 14-15; US Department of State 2008 www.state.gov 5; GAATW Human Rights in Practice 122.

152 Minnie "Sexual Offences" 540-541.

153 Kruger Organised Crime 1, 3-4.

154 Kruger Organised Crime 1.

155 NDPP v Mohamed 20022 SACR 196 (CC) 203-204 para 15-16.

156 For an in-depth discussion of this act, see Kruger Organised Crime 11-162; Burchell Criminal Law 970-1019.

157 Preamble Prevention of Organised Crime Act 121 of 1998; Kruger Organised Crime 9.

158 Kruger Organised Crime 8, 11-124; Burchell Criminal Law 973, 976-1011; IOM Countertrafficking 87; S v De Vries 20091 SACR 613 (C) 619D-624H, 628H-629F. 
any formal or informal ongoing organisation, association, or group of three or more persons, which has as one of its activities the commission of one or more criminal offences, which has an identifiable name or identifying sign or symbol, and whose members individually or collectively engage in or have engaged in a pattern of criminal gang activity. ${ }^{159}$

Raymond, ${ }^{160}$ Dawes, Bray and Van der Merwe, ${ }^{161}$ and Obokata ${ }^{162}$ report that organised criminal groups are increasingly associated with human trafficking, primarily in order to make huge illegal profits. ${ }^{163}$ The increased involvement of organised criminal groups in human trafficking poses a substantial threat not only to victims, but also to national and international security and stability. ${ }^{164}$ Therefore, the Prevention of Organised Crime Act may be used in appropriate circumstances as a tool to deal with money-laundering and with criminal gang and racketeering activities in human trafficking cases. ${ }^{165}$ In the ground-breaking case of $S v$ Sayed, ${ }^{166}$ the prosecution secured a conviction on charges of managing an enterprise, ${ }^{167}$ moneylaundering, ${ }^{168}$ and acquiring, using or possessing the proceeds of illegal activities ${ }^{169}$ in terms of this act. ${ }^{170}$ The convictions pertained to trafficking-related activities where Thai women were recruited in Thailand to work as sex workers at a brothel in South Africa. ${ }^{171}$ The accused, who managed the brothel, retained the passports of the Thai women as security until the women complied with the terms of their so-called

159 S 1 Prevention of Organised Crime Act 121 of 1998.

160 Raymond 2002 Women's International Forum 493. These criminal groups are widespread and expand over continents, for example an estimated 5000 organised criminal groups constitute the Russian Mafia alone - Raymond 2002 Women's International Forum 493. As regards organised crime in the South African context, criminal gang activity is rife, especially in the Western Cape, where it is estimated that there are about 100000 gang members on the Cape Flats - Kruger Organised Crime 54-55.

161 Dawes, Bray and Van der Merwe Child Well-being 259.

162 Obokata Trafficking of Human Beings 46-47.

163 Melvin Human Trafficking 22; International Crime and Terrorism 2004 www.dfait-maeci.gc.ca 1.

164 Singh 2004 CILSA 344-345; The Future Group 2007 tfgwebmaster.web.aplu.net 2; Dougherty and Burke 2008 America 13; Lee Human Trafficking 2.

165 IOM Counter-trafficking 87; Mnisi "Trafficking in Persons" 21; HSRC 2010 www.hsrc.ac.za 52. Gastrow Organised Crime 41, in a study of organised crime in the Southern African Development Community countries, confirms the cross-border trafficking in women and children in South Africa.

166 Judgment was delivered on 18 March 2010 in S v Sayed (unreported case no. 041/2713/2008) in the Durban Regional Court. Further convictions in terms of this act for trafficking-related activities concerning illegal kidney transplant operations were secured in $S v$ Netcare Kwa-Zulu (Proprietary) Limited (unreported case no. 41/1804/2010 8 November 2010, Durban Regional Court); see also Allain 2011 Med L Rev 119-122.

167 Section 2(1) Prevention of Organised Crime Act 121 of 1998.

168 Section 4 Prevention of Organised Crime Act 121 of 1998.

169 Section 6 Prevention of Organised Crime Act 121 of 1998.

170 S v Sayed (unreported case no. 041/2713/2008, 18 March 2010, Durban Regional Court) 1-2.

$171 S$ v Sayed (unreported case no. 041/2713/2008, 18 March 2010, Durban Regional Court) 5. 
"contract" by generating the amount of R60 000 each from prostitution for the accused. $^{172}$

In addition, the act may also be utilised to take the profit out of human trafficking. This can be done by recovering the proceeds of unlawful activities, as well as by the civil forfeiture of criminal assets that have either been used to commit an offence or are the proceeds of such an offence. ${ }^{173}$ For example, the brothel or building accommodating the persons trafficked into forced prostitution is an instrumentality of the offence of keeping a brothel ${ }^{174}$ and may be forfeited in terms of this act. ${ }^{175}$

\subsubsection{Prevention and Combating of Corrupt Activities Act 12 of 2004}

Corrupt activities are typically part of human trafficking offences. ${ }^{176}$ Such corrupt activities can be punished under the Prevention and Combating of Corrupt Activities Act 12 of 2004, which provides for the strengthening of measures to prevent and combat corruption. ${ }^{177}$ The act unbundles the crime of corruption by creating a

172 S v Sayed (unreported case no. 041/2713/2008, 18 March 2010, Durban Regional Court) 5-6. In $S$ v Mudaly (unreported pending case no. 41/890/2007, Durban Regional Court) the accused are also standing trial for offences in terms of the Prevention of Organised Crime Act 121 of 1998 personal communications with the prosecutor in the case, Advocate V Lotan, National Prosecuting Authority.

173 The act provides for various restraint orders (s 26), confiscation orders (s 18) and realisation orders (s 30-33), as well as for civil preservation (s 38-39) and forfeiture orders (s 50) for the recovery of property; see also Kruger Organised Crime 59-124; SALRC 2008 www.justice .gov.za 23; SOCA Unit 2009 www.info.gov.za 2. The Asset Forfeiture Unit within the National Prosecuting Authority deals with the seizure of "criminal assets that are proceeds of crime or have been involved in the commission of a crime either through a criminal or civil process" - NPA 2010a www.pmg.org.za 33-35; HSRC 2010 www.hsrc.ac.za 52-53.

174 Section 2 Sexual Offences Act 23 of 1957.

175 In National Director of Public Prosecutions v Geyser 20082 SACR 103 (SCA) para 16-17, 31, 36 , the court found that immovable property bought, revamped and used only for the purpose of the offence of keeping a brothel in contravention of s 2 of the Sexual Offences Act 23 of 1957 constituted an instrumentality of the offence of keeping a brothel. For this reason, the specific building may be forfeited under the Prevention of Organised Crime Act 121 of 1998, and such forfeiture is not disproportionate, but serves the remedial purpose of the act to curb crime that is undertaken as a business - Mnisi "Trafficking in Persons" 22. The Supreme Court of Appeal provided further clarity by stating that "in giving meaning to 'instrumentality of an offence' the focus is not on the state of mind of the owner, but on the role the property plays in the commission of the crime" - National Director of Public Prosecutions v R O Cook Properties (Pty) Ltd; National Director of Public Prosecutions v 37 Gillespie Street Durban (Pty) Ltd; National Director of Public Prosecutions v Seevnarayan 20042 SACR 208 (SCA) 226 para 21; see also Mnisi "Trafficking in Persons" 23.

176 Haynes 2004 Hum Rts Q 226, 229; Brennan 2005 International Migration 42; Foundation against Trafficking in Women et al Human Rights Standards 4; Singh 2004 CILSA 344; UNODC Toolkit xxi; GAATW Human Rights in Practice 13; UN.GIFT "Human Trafficking" 14; Shelley "Human Trafficking" 122.

177 Long title Prevention and Combating of Corrupt Activities Act 12 of 2004. 
general, broad and all-encompassing offence of corruption, as well as various specific offences relating to different corrupt activities. ${ }^{178}$

The gist of the general offence of corruption is the offering or giving of a benefit to another to act illegally or dishonestly, or to violate a legal duty, as well as the receiving of or agreement to receive a benefit for such a purpose. ${ }^{179}$ Other offences in the act include the corruption of public officers, judicial officers, prosecutors and witnesses. ${ }^{180}$ Corruption used to facilitate human trafficking can indeed be punished by means of these anti-corruption offences.

On conviction of most of the above-mentioned offences, the act provides for stringent sentences by stipulating that such a convicted person is liable-

(a) in the case of a sentence to be imposed by a High Court, to a fine or to imprisonment up to a period for imprisonment for life;

(b) in the case of a sentence to be imposed by a regional court, to a fine or to imprisonment for a period not exceeding 18 years; or

(c) in the case of a sentence to be imposed by a magistrate's court, to a fine or to imprisonment for a period not exceeding five years. ${ }^{181}$

\subsubsection{Drugs and Drug Trafficking Act 140 of 1992}

McClain and others report that criminal gangs involved in human trafficking also commit other serious crimes, such as drug trafficking. ${ }^{182}$ To facilitate the smooth running of their trafficking operation, traffickers often administer drugs to their victims to make them compliant and facilitate control over them. ${ }^{183}$

178 Section 3-21 Prevention and Combating of Corrupt Activities Act 12 of 2004; Snyman Criminal Law 411-426; Burchell Criminal Law 891-895.

179 Section 3 Prevention and Combating of Corrupt Activities Act 12 of 2004.; Snyman Criminal Law 411-423; Burchell Criminal Law 892-893.

180 Section 4-21 Prevention and Combating of Corrupt Activities Act 12 of 2004; Snyman Criminal Law 423-426; Burchell Criminal Law 893-895.

181 Section 26(1) Prevention and Combating of Corrupt Activities Act 12 of 2004.provides for these sentences on conviction in terms of s 3-16, 18 or 21; Burchell Criminal Law 895.

182 McClain 2007 Vanderbilt J Transn'l L 581; UNODC Toolkit xix; Kreston 2007 Child Abuse Research in South Africa 38; Morawska "Trafficking" 101; Shelley "Human Trafficking" 123.

183 Haynes 2004 Hum Rts Q 226; Gajic-Veljanoski and Stewart 2007 Trans-cultural Psychiatry 341; US Department of State 2007 www.state.gov 28. 
The Drugs and Drug Trafficking Act 140 of 1992 criminalises the possession of as well as the trafficking in certain drugs ${ }^{184}$ and can thus be used to punish traffickers involved in such drug-related offences. The punishment for drug trafficking offences is severe and imprisonment of up to 25 years can be imposed for trafficking in dangerous and undesirable dependence-producing substances such as cannabis, heroin and morphine. ${ }^{185}$

\subsubsection{Human Tissue Act 65 of 1983}

The trafficking of persons for the removal of their body parts is a documented form of human trafficking. ${ }^{186}$ Apart from using this form of trafficking for illegal organ and tissue transplants, the 2008 study of the International Organization for Migration on in-country trafficking in South Africa suggests the existence of trafficking for body parts, including eyes, tongues and genitals, to be used in traditional African potions. $^{187}$

For the interim period until chapter 8 of the National Health Act 61 of 2003 comes into operation, the Human Tissue Act 65 of $1983^{188}$ regulates organ transplants and sets requirements for the removal of tissue, blood and gametes from the bodies of living persons. ${ }^{189}$ Apart from payment to authorised persons or institutions, the act prohibits payment for the "acquisition or supply of any tissue or gamete for or to another person" for medical or dental purposes. ${ }^{190}$ In applicable cases, this act may be used to prosecute persons for conduct related to the trafficking of persons for the removal of their body parts. ${ }^{191}$ While this act prohibits the removal of tissue from living bodies in any other manner or for any other purpose than is prescribed in the

184 Sections 4 and 5 Drugs and Drug Trafficking Act 140 of 1992.

185 Section 17 Drugs and Drug Trafficking Act 140 of 1992.

186 IOM 2008 iom.org.za 60-63; Dottridge and Weissbrodt 1999 German Yearbook of International Law 282; UN.GIFT "Human Trafficking" 4; Ncube "Possible Contribution" 4; Hodgkin and Newell Implementation Handbook 527; Snyman "Victims" 284; Fellows 2008 www.scribd.com 46.

187 IOM 2008 iom.org.za 60-63; see also SALRC 2006 www.doj.gov.za 30; Snyman "Victims" 284285; Fellows 2008 www.scribd.com 7, 29-31, 46.

188 The Human Tissue Act 65 of 1983 has been repealed by s 93(1) of the National Health Act 61 of 2003. Although most sections of the National Health Act 61 of 2003 have been in force since 2005 , chapter 8 of this act, which contains provisions relevant to the present study, is not yet in operation - Proc R19 in GG 27503 of 18 April 2005; Proc R20 in GG 33187 of 14 May 2010.

189 Section 18-23 Human Tissue Act 65 of 1983; Slabbert 2009 Obiter 510-511; Fellows 2008 www.scribd.com 42.

190 S 28(1) Human Tissue Act 65 of 1983.

191 UN.GIFT "Human Trafficking" 2; Hodgkin and Newell Implementation Handbook 523. 
act, the punishment for such an offence is a fine of up to R2 000 or imprisonment for a period not exceeding one year, or both. ${ }^{192}$ These sanctions are inadequate to deter traffickers who practise and profit from this type of trafficking. ${ }^{193}$

\subsubsection{National Health Act 61 of 2003}

Like the Human Tissue Act 65 of 1983 (Human Tissue Act), the National Health Act 61 of 2003 (National Health Act) also criminalises commerce in human tissue. ${ }^{194}$ Apart from other provisions, payment for the acquisition or supply of tissue, blood, blood products or gametes is strictly regulated. ${ }^{195}$ The act stipulates that it is an offence "to sell or trade in tissue, gametes, blood or blood products" and provides for imprisonment of up to five years for the commission of such an offence. ${ }^{196}$ In applicable circumstances, conduct related to trafficking for the removal of body parts may be prosecuted under this act, when the relevant sections of the act come into operation.

A concern is the fact that the act does not criminalise the possession of human tissue or human blood. Cases where a person is found in possession for example of a human head, genitals or other human body parts, are problematic. The law is not clear on how to deal with instances where a person is found in possession of tissue or human blood but it cannot be proven that the person found in possession of such tissue or blood has killed the person to whom such tissue or blood belongs or has the intention to sell or trade in such tissue or blood. ${ }^{197}$

Another concern is that the National Health Act does not provide for stringent punishment. Although the penalty for trading in human tissue or blood is increased from a maximum term of imprisonment of one year in terms of the Human Tissue Act to five years under this act, it is doubtful that the penalty is of such a nature that it will successfully deter offenders.

192 S 34 Human Tissue Act 65 of 1983; Fellows 2008 www.scribd.com 42.

193 Parliamentary Committee on Justice and Constitutional Development 2010 www.pmg.org.za 8; Fellows 2008 www.scribd.com 42.

194 Section 60 National Health Act 61 of 2003; Slabbert 2009 Obiter 511.

195 Section 60(1) National Health Act 61 of 2003.

196 Section 60(4) National Health Act 61 of 2003; see also Slabbert 2009 Obiter 511.

197 Personal communications with Advocate L Stuurman, South African Law Reform Commission. 


\subsubsection{Films and Publications Act 65 of 1996}

The Films and Publications Act 65 of 1996, as amended, regulates the creation, production, possession and distribution of specific publications and films by means of classification, the imposition of age restrictions, and the provision of consumer advice. $^{198}$ In addition, children are specifically protected against sexual exploitation or degradation by criminalising the exploitative use of children in pornographic publications and films or on the Internet. ${ }^{199}$ The act provides for numerous offences, including the possession or creation of a film or publication which contains child pornography. ${ }^{200}$ Moreover, it is also punishable for a person with knowledge of an offence involving child pornography not to report it to the South African Police Service. $^{201}$

Perpetrators involved in sex trafficking may distribute or possess child pornography, which includes the storage thereof on computer or by way of an electronic datastorage medium such as a memory stick or a compact disc. ${ }^{202}$ They may even use trafficked persons to create child pornography in publications, in films or on the Internet in order to advertise the services their victims provide. ${ }^{203}$ Such conduct can be successfully prosecuted under this act. It is to be welcomed that persons convicted of creating a film or publication which contains child pornography or who are in possession of or distribute such material can be sentenced to imprisonment for up to 10 years. $^{204}$

198 Section 2(a) Films and Publications Act 65 of 1996; Minnie "Sexual Offences" 537-538.

199 Section 2(b), read with s 27 Films and Publications Act 65 of 1996; Minnie "Sexual Offences" 537-538.

200 Section 27(1)(a) Films and Publications Act 65 of 1996.

201 Section 27(2)(a) Films and Publications Act 65 of 1996; see also Minnie "Sexual Offences" 538.

202 Section 1 Films and Publications Act 65 of 1996 defines the term "possession", in relation to a film or publication, and without derogating from its ordinary meaning, to include "keeping or storing in or on a computer or computer system or computer data storage medium and also having custody, control or supervision on behalf of another person".

203 The term "child pornography" is broadly defined in s 1 Films and Publications Act 65 of 1996.

204 Section 30(1)(A) Films and Publications Act 65 of 1996. 


\subsubsection{Sexual Offences Act 23 of 1957}

Some provisions of the Sexual Offences Act 23 of $1957^{205}$ are still in operation and may apply in cases of human trafficking for sexual exploitation. The act proscribes the keeping of a brothel, ${ }^{206}$ which is defined as any house or place kept for the purposes of having unlawful carnal intercourse or any other lewd or indecent purpose. ${ }^{207}$ Trafficking agents were convicted of this offence in $S v$ Andrews ${ }^{208}$ as well as in $S v$ Sayed. ${ }^{209}$ The act further provides that certain persons are "deemed to keep a brothel", ${ }^{210}$ for example a person managing, or assisting in managing, a brothel or knowingly receiving money at a brothel. ${ }^{211}$ This section casts the net wide so that perpetrators sharing in the profits or assisting in the running of a brothel as part of a trafficking scenario can also be prosecuted.

Offences that may find application in a human trafficking scenario, as was illustrated in $S v$ Sayed, ${ }^{212}$ are the procurement of a female in order to have unlawful carnal intercourse, ${ }^{213}$ living on the earnings of prostitution ${ }^{214}$ or the facilitation of prostitution. ${ }^{215}$ In addition, permitting premises to be used for the purposes of prostitution is also criminalised under this act. ${ }^{216}$ The National Prosecuting Authority reported convictions in terms of this act for human trafficking activities in $S v$ Sawatkan and $S v$ Wiphatawaithaya. ${ }^{217}$

205 A number of sections of this act were repealed by the Criminal Law (Sexual Offences and Related Matters) Amendment Act 32 of 2007, namely s 9, 11, 12(2), 13-15, 18, 18A, 20A - see the schedule to this act.

206 Section 2 Sexual Offences Act 23 of 1957; Minnie "Sexual Offences" 535.

207 Section 1 Sexual Offences Act 23 of 1957; Minnie "Sexual Offences" 534-535; see also National Director of Public Prosecutions v Geyser 20082 SACR 103 (SCA) 116, where the court ordered, in terms of the provisions of the Prevention of Organised Crime Act 121 of 1998, the forfeiture to the state of the immovable property used as a brothel in a criminal enterprise.

208 S v Andrews (unreported case no 27/50/1998) in which the accused were sentenced in the Cape Town Regional Court on 30 July 2004; see also NPA 2010a www.pmg.org.za 11.

$209 S$ v Sayed (unreported case no. 041/2713/2008; 18 March 2010, Durban Regional Court).

210 Section 3(b)-(c) Sexual Offences Act 23 of 1957.

211 Section 3 Sexual Offences Act 23 of 1957.

212 In $S$ v Sayed (unreported case no. 041/2713/2008) the accused were convicted on 18 March 2010 in the Durban Regional Court of contravening ss 2, 12A(1), 10, 17, 20(1)(a) and (c) of the Sexual Offences Act 23 of 1957.

213 Section 10 Sexual Offences Act 23 of 1957.

214 Section 20(1) Sexual Offences Act 23 of 1957. This section was amended by the Criminal Law (Sexual Offences and Related Matters) Amendment Act 32 of 2007 - see s 68, read with the schedule to this act; Snyman Criminal Law 353.

215 Section 12A(1) Sexual Offences Act 23 of 1957; see also Minnie "Sexual Offences" 536.

216 Section 17 Sexual Offences Act 23 of 1957.

217 NPA 2010a http:www.pmg.org.za 12. 
2.2.14 Criminal Law (Sexual Offences and Related Matters) Amendment Act 32 of 2007

Human trafficking, especially for sexual exploitation, invariably involves the sexual abuse of the trafficked person. With a multitude of sexual offences now included in a single statute, namely the Criminal Law (Sexual Offences and Related Matters) Amendment Act 32 of 2007 (Sexual Offences Amendment Act), this act may be used successfully to prosecute and punish perpetrators involved in human trafficking for the purposes of various acts of sexual exploitation. ${ }^{218}$

Although a detailed discussion of the wide array of offences contained in this act falls outside the scope of this article, a brief overview is given. Far-reaching law reforms were introduced by replacing the common law offences of rape and indecent assault with the extended statutory offences of rape $^{219}$ and sexual assault. ${ }^{220}$ The exceptionally broad definitions of the prohibited conduct in both the offences of rape $^{221}$ and sexual assault ${ }^{222}$ have increased the protection against sexual misconduct significantly. In addition, a number of offences against persons of 18 years and older are also provided for. ${ }^{223}$ These offences include engaging the sexual services of such persons ${ }^{224}$ or compelling them to witness sexual offences, sexual acts or self-masturbation, ${ }^{225}$ as well as the exposure of the genital organs, anus or

218 Minnie "Sexual Offences" 541-562.

219 Section 3 Criminal Law (Sexual Offences and Related Matters) Amendment Act 32 of 2007: "Any person ('A') who unlawfully and intentionally commits an act of sexual penetration with a complainant ('B'), without the consent of $B$, is guilty of the offence of rape." For a discussion of the statutory offence of rape, see Snyman Criminal Law 355-369; Minnie "Sexual Offences" 546 547.

220 Section 5(1) Criminal Law (Sexual Offences and Related Matters) Amendment Act 32 of 2007. For a discussion of the statutory offence of sexual assault, see Snyman Criminal Law 371-378; Minnie "Sexual Offences" 547-548.

221 The offence of rape prohibits "sexual penetration", which is defined in $\mathbf{s} 1$ to include "any act which causes penetration to any extent whatsoever by - (a) the genital organs of one person into or beyond the genital organs, anus, or mouth of another person; (b) any other part of the body of one person or, any object, including any part of the body of an animal, into or beyond the genital organs or anus of another person; or (c) the genital organs of an animal, into or beyond the mouth of another person". See also Minnie "Sexual Offences" 546-547.

222 The offence of sexual assault prohibits "sexual violation", which is defined in s 1 Criminal Law (Sexual Offences and Related Matters) Amendment Act 32 of 2007; see also Minnie "Sexual Offences" 547-548.

223 Sections 8-11 Criminal Law (Sexual Offences and Related Matters) Amendment Act 32 of 2007; see the discussion in Snyman Criminal Law 381-387.

224 Section 11 Criminal Law (Sexual Offences and Related Matters) Amendment Act 32 of 2007.

225 Section 8 Criminal Law (Sexual Offences and Related Matters) Amendment Act 32 of 2007. 
female breasts ("flashing") 226 and the exposure of child pornography to persons 18 years or older. ${ }^{227}$

Notably, numerous offences have also been introduced to provide special protection for children. ${ }^{228}$ What is particularly useful for the purpose of prosecuting agents involved in child sex trafficking are the broadly defined offences of sexual exploitation, ${ }^{229}$ promoting child sex tours, ${ }^{230}$ and the sexual grooming of children. ${ }^{231}$ Burchell emphasises that the grooming of children so as to encourage and prepare them to commit sexual offences has become a serious concern in South Africa. ${ }^{232}$ Minnie points out that "grooming is a complex process to define". ${ }^{233}$ Offenders use various methods to overcome a child's resistance and to lure him or her into sexual acts. Youths are ensnared into a so-called "friendship" or "love relationship" by means of communications, especially via the Internet, and by way of meetings where gifts such as clothing, jewellery, music compact discs and cellphones are given freely as a token of "affection". ${ }^{234}$ Once a trust relationship is established, children are typically provided with alcohol and drugs and are gradually introduced to sexual acts, which eventually develop into a demand for abusive sexual services. ${ }^{235}$

Other offences designed to protect children include the prohibition against using children for child pornography ${ }^{236}$ and against children being exposed to child pornography or pornography. ${ }^{237}$ The Sexual Offences Amendment Act also provides

226 Section 9 Criminal Law (Sexual Offences and Related Matters) Amendment Act 32 of 2007.

227 Section10 Criminal Law (Sexual Offences and Related Matters) Amendment Act 32 of 2007.

228 Sections 15-22 Criminal Law (Sexual Offences and Related Matters) Amendment Act 32 of 2007; see the discussion in Snyman Criminal Law 392-398; Minnie "Sexual Offences" 550-562.

229 Section 17(1) Criminal Law (Sexual Offences and Related Matters) Amendment Act 32 of 2007; see also Minnie "Sexual Offences" 553-555.

230 Section 17(6) Criminal Law (Sexual Offences and Related Matters) Amendment Act 32 of 2007.

231 Section 18(2) Criminal Law (Sexual Offences and Related Matters) Amendment Act 32 of 2007; see also Minnie "Sexual Offences" 555-558.

232 Burchell Criminal Law 739.

233 Minnie "Sexual Offences" 556-558.

234 Burchell Criminal Law 739; Fritz "Child Slavery/Trafficking" 5; Minnie "Sexual Offences" 556-558.

235 Fritz "Child Slavery/Trafficking" 5; Burchell Criminal Law 698, 739-740; Minnie "Sexual Offences" 556-558.

236 Section 20(1) Criminal Law (Sexual Offences and Related Matters) Amendment Act 32 of 2007; see also Minnie "Sexual Offences" 559.

237 Section 19 Criminal Law (Sexual Offences and Related Matters) Amendment Act 32 of 2007; see also Minnie "Sexual Offences" 558-559. 
special protection like the protection for children for persons who are mentally disabled. ${ }^{238}$

\subsubsection{International Co-operation in Criminal Matters Act 75 of 1996}

International judicial cooperation, in particular among countries of origin, transit and destination, is essential to combat human trafficking effectively, especially crossborder trafficking. ${ }^{239}$ The International Co-operation in Criminal Matters Act 75 of 1996 contributes in this regard by facilitating cooperation between South Africa and foreign countries in criminal matters. ${ }^{240}$ These criminal matters include the mutual provision of evidence. ${ }^{241}$ In cases where it is in the interests of justice, the act provides for the issuing of a letter requesting assistance from a foreign state in obtaining evidence from a person who is present in such a foreign state. ${ }^{242}$

This act also facilitates the mutual execution of sentences and compensatory orders. ${ }^{243}$ For example, where a person who is sentenced to the payment of a fine or of compensation to another person has property only in a foreign state from which the fine or compensation can be recovered, the court may issue a letter of request in which assistance is sought in this regard from the relevant foreign state. ${ }^{244}$

Notably, the act further provides for the confiscation and transfer of the proceeds of crime between the Republic of South Africa and foreign states. ${ }^{245}$ In terms of these provisions, assistance may be requested from a foreign state in order to execute a confiscation order, issued in South Africa, in a foreign state in which the person against whom the order is made owns property. ${ }^{246} \mathrm{~A}$ foreign state may on the same basis request South Africa to execute a foreign confiscation order in the Republic. ${ }^{247}$

238 Section 23-26 Criminal Law (Sexual Offences and Related Matters) Amendment Act 32 of 2007; Snyman Criminal Law 398-400.

239 David 2007 Trends \& Issues in Crime and Criminal Justice 1; UNODC 2008 www.unodc.org 7; Planitzer Counter-trafficking Cooperation 17-18; UNODC 2009 www.unodc.org 83.

240 Long title of the International Co-operation in Criminal Matters Act 75 of 1996.

241 Sections 2-12 International Co-operation in Criminal Matters Act 75 of 1996.

242 Section 2 International Co-operation in Criminal Matters Act 75 of 1996.

243 Sections 13-18 International Co-operation in Criminal Matters Act 75 of 1996.

244 Section 13 International Co-operation in Criminal Matters Act 75 of 1996.

245 Sections 19-26 International Co-operation in Criminal Matters Act 75 of 1996.

246 Section 19 International Co-operation in Criminal Matters Act 75 of 1996.

247 Section 20 International Co-operation in Criminal Matters Act 75 of 1996. 
These provisions may be used to ensure justice in some human trafficking cases, especially where confiscation orders against influential organised crime networks can be enforced only in another country in which the perpetrators own property. ${ }^{248}$

\section{$3 \quad$ Interim human trafficking offences}

Apart from numerous existing common law and statutory provisions that may be applied to prosecute trafficking agents, trafficking-specific provisions were also recently introduced into South African law.

\subsection{Children's Act 38 of 2005}

While the South African Law Reform Commission was still in the process of investigating law reform concerning human trafficking, ${ }^{249}$ interim provisions on trafficking in children were included in the Children's Act 38 of 2005 (Children's Act) in partial compliance with the Protocol to Prevent, Suppress and Punish Trafficking in Persons, Especially Women and Children (Palermo Protocol). ${ }^{250}$ The purpose of the trafficking provisions in chapter 18 of this act is to combat trafficking in children and to give effect to the Palermo Protocol, which is incorporated into the law of the Republic of South Africa (the Republic). ${ }^{251}$

In short, the Children's Act creates two main trafficking offences. First, the trafficking of children by natural or juristic persons for an exploitative purpose is criminalised. ${ }^{252}$

248 A number of sources have reported the involvement of organised criminal networks in human trafficking activities - Obokata Trafficking of Human Beings 46-47; Raymond 2002 Women's International Forum 493; Melvin Human Trafficking 22; International Crime and Terrorism 2004 www.dfait-maeci.gc.ca 1; Singh 2004 CILSA 344-345; The Future Group 2007tfgwebmaster.web.aplu.net 2; Dougherty and Burke 2008 America 13; Lee Human Trafficking 2. Kruger Organised Crime 1, 8 emphasises the international approach that the proceeds of crime should be confiscated by state authorities to remove the incentive for crime.

249 SALRC 2004 www.doj.gov.za 1-3: SALRC 2006 www.doj.gov.za 1; SALRC 2008 www.justice.gov.za 7; Kassan "Trafficking in Children" 18-9.

250 SALRC 2006 www.doj.gov.za 3; Kassan "Trafficking in Children" 18-10; Kassan and Mahery Protective Measures 200; HSRC 2010 www.hsrc.ac.za 41.

251 See ss 281-282 of the Children's Act 38 of 2005; Kassan "Trafficking in Children" 18-13, 14; Dawes, Bray and Van der Merwe Child Well-being 247; Kassan and Mahery Protective Measures 200; Bosman-Sadie and Corrie Children's Act 285; HSRC 2010 www.hsrc.ac.za 42.

252 Section 284(1) Children's Act 38 of 2005: "No person, natural or juristic, or a partnership may traffic a child or allow a child to be trafficked." See also SALRC 2008 www.justice.gov.za 12; Kassan "Trafficking in Children" 18-15, 16; Kassan and Mahery Protective Measures 203; Bosman-Sadie and Corrie Children's Act 286-287; HSRC 2010 www.hsrc.ac.za Mar 42. 
Such trafficking is regarded as a serious offence and imprisonment of up to 20 years may therefore be imposed. ${ }^{253}$ Additional protection for children is provided in that it is no defence for the perpetrator that the child or the person having control over the child has consented to the exploitation or illegal adoption. ${ }^{254}$ Furthermore, provided that the exploitative purpose is proven, it is also no defence on a charge of trafficking in children that the intended exploitation or adoption did not occur. ${ }^{255}$ The Palermo Protocol's obligation to criminalise attempts, participation as accomplices, and organising or directing others to commit this crime is covered by existing legislation on attempt, conspiracy, and incitement to commit a crime. ${ }^{256}$

Apart from criminalising the crime of trafficking, the act also criminalises certain behaviour facilitating trafficking in children in order to cast the net wide enough to include the various role-players that usually profit from this crime. ${ }^{257}$ On conviction of this crime of facilitating trafficking in children, a maximum of 10 years' imprisonment may be imposed. ${ }^{258}$ In short, the prohibited behaviour entails leasing any property for the purpose of harbouring a trafficked child or distributing information alluding to trafficking. Further, internet service providers are required to report any site on their servers that contains such prohibited information. ${ }^{259}$

253 Sections 305(1) and (8) Children's Act 38 of 2005; Kassan and Mahery Protective Measures 203.

254 Section 284(2)(a) Children's Act 38 of 2005; Kassan "Trafficking in Children" 18-16; Kassan and Mahery Protective Measures 203; Bosman-Sadie and Corrie Children's Act 287.

255 Section 284(2)(b) Children's Act 38 of 2005; Kassan "Trafficking in Children" 18-16; Kassan and Mahery Protective Measures; Bosman-Sadie and Corrie Children's Act 287.

256 Section 18 of the Riotous Assemblies Act 17 of 1956; Snyman Criminal Law 283-305; Burchell Criminal Law 619-657; see also 2.2.1 above.

257 Section 28 Children's Act 38 of 20055; Kassan and Mahery Protective Measures 203-204; Bosman-Sadie and Corrie Children's Act 287-288.

258 Section 305(6) Children's Act 38 of 2005. If a person is convicted more than once of this offence, the sentence may be increased to a maximum of 20 years' imprisonment $-\mathrm{s} 305(7)$; SALRC 2008 www.justice.gov.za 12.

259 Section 285 Children's Act 38 of 2005: "(1) No person, natural or juristic, or a partnership, may (a) knowingly lease or sublease or allow any room, house, building or establishment to be used for the purpose of harbouring a child who is a victim of trafficking; and (b) advertise, publish, print, broadcast, distribute or cause the advertisement, publication, printing, broadcast or distribution of information that suggests or alludes to trafficking by any means, including the use of the Internet or other information technology. (2) Every Internet service provider operating in the Republic must report to the South African Police Service any site on its server that contains information in contravention of subsection (1)." See also Kassan "Trafficking in Children" 18-17, 18; Kassan and Mahery Protective Measures:203; Bosman-Sadie and Corrie Children's Act 287-288; HSRC 2010 www.hsrc.ac.za 42. 
The definition in the Children's Act of the term "trafficking"260 in relation to a child is similar to the definition of "trafficking in persons" contained in the Palermo Protocol. ${ }^{261}$ However, there are a number of differences between the definitional formulations. First, the definition in the Children's Act is somewhat broader, in that terms such as "supply" are added as prohibited actions. Secondly, adoption secured through illegal means is also included in the definition of trafficking in children. ${ }^{262}$ In agreement with Kassan, ${ }^{263}$ it must be pointed out that an "illegal adoption" means the "exploitation of the adoptive system and laws and not necessarily the exploitation of the adopted child". ${ }^{264}$

Even where a child is illegally adopted, the adoptive parents may not have the intention to exploit the child at all. Such illegal adoptions must be distinguished from illegal adoptions that constitute trafficking in children in terms of the Children's Act. For an illegal adoption to qualify as trafficking, Kassan submits that an interpretation should be followed in line with that in the Palermo Protocol, namely that the primary intention of the illegal adoption must be to exploit the child. ${ }^{265}$

Thirdly, the definition of trafficking in the Children's Act also differs from the provision in the Palermo Protocol regarding the so-called "means" element. ${ }^{266}$ The Palermo Protocol requires that the perpetrator must use at least one of the listed improper

260 Section 1 Children's Act 38 of 2005: "'trafficking', in relation to a child - (a) means the recruitment, sale, supply, transportation, transfer, harbouring or receipt of children, within or across the borders of the Republic - (i) by any means, including the use of threat, force or other forms of coercion, abduction, fraud, deception, abuse of power or the giving or receiving of payments or benefits to achieve the consent of a person having control of a child; or (ii) due to a position of vulnerability, for the purpose of exploitation; and (b) includes the adoption of a child facilitated or secured through illegal means."

261 Article 3(a) Palermo Protocol (2000); Kassan "Trafficking in Children" 18-10, 11, 16; Dawes, Bray and Van der Merwe Child Well-being 251-252; Bosman-Sadie and Corrie Children's Act 285; HSRC 2010 www.hsrc.ac.za 42.

262 Section 1 Children's Act 38 of 2005; SALRC 2008 www.justice.gov.za 13; HSRC 2010 www.hsrc.ac.za 42. For a critical view on the insertion of the illegal adoption of a child into the definition of "trafficking", see Kassan and Mahery Protective Measures 202-203.

263 Kassan "Trafficking in Children" 18-12.

264 Kassan "Trafficking in Children" 18-12.

265 Kassan "Trafficking in Children" 18-12; see also Kassan and Mahery Protective Measures 202203. The Official Interpretative Notes (Travaux Préparatoires) to the Palermo Protocol indicate that "where illegal adoption amounts to a practice similar to slavery as defined in article 1, paragraph (d), of the Supplementary Convention on the Abolition of Slavery, the Slave Trade, and Institutions and Practices Similar to Slavery, it will also fall within the scope of the Protocol" UN General Assembly 2000 www.unodc.org para 66; see also Jordan 2002 www.walnet.org 910.

266 Bosman-Sadie and Corrie Children's Act 285. 
means, such as force, threat, fraud or deception, when adults are trafficked, ${ }^{267}$ but not for the trafficking of a child under the age of 18 years. ${ }^{268}$ In providing special protection for children, the Palermo Protocol lays down that the prescribed action element, namely the recruitment, transportation, transfer, harbouring or receiving of a child for the purpose of exploitation, constitutes trafficking in persons, even if none of the means set out in the definition were used. ${ }^{269}$ Unlike the Palermo Protocol, the Children's Act provides that trafficking in children requires the prohibited action to be committed by "any means, including the use of threat, force or other forms of coercion, abduction, fraud, deception" for the purpose of exploitation. ${ }^{270}$ One interpretation of "any means" is that no means are required for child trafficking, and thus the definition in the Children's Act corresponds with the definition in the Palermo Protocol. Then again, Kassan points out that a different interpretation of "any means" is that the Children's Act does require one of the specified means to be present to constitute trafficking in children. ${ }^{271}$ The latter interpretation is problematic, in that, if the means element is required for trafficking in children, it is not in line with the Palermo Protocol, which waives the means element in regard to child trafficking. ${ }^{272}$ The formulation of the "means" element in the definition of "trafficking" in the Children's Act has therefore been "criticised for creating a greater evidentiary burden" than is required by the Palermo Protocol. ${ }^{273}$

A fourth difference pertains to the definition of the term "exploitation" in the Children's Act, which is similar to but not identical to that in the Palermo Protocol. Both definitions of "exploitation" implicitly cover trafficking for the purposes of all types of exploitation. However, the Palermo Protocol stipulates that the term "exploitation" "includes at a minimum" certain examples of exploitative purposes. ${ }^{274}$ The Children's Act also covers these examples of exploitation, but adds other examples as well,

267 Article 3(a) Palermo Protocol (2000); see also SALRC 2006 www.doj.gov.za 14; Kassan "Trafficking in Children" 18-16.

268 Article 3(c) Palermo Protocol (2000) see also SALRC 2006 www.doj.gov.za 14; Kassan "Trafficking in Children" 18-16.

269 Article 3(c) Palermo Protocol (2000); SALRC 2006 www.doj.gov.za 14.

270 Section 1 Children's Act 38 of 2005; Kassan and Mahery Protective Measures 202.

271 Kassan "Trafficking in Children" 18-11; Kassan and Mahery Protective Measures 202.

272 Kassan "Trafficking in Children" 18-11; Kassan and Mahery Protective Measures 202.

273 For a critical view on the "means" element in the definition of "trafficking" in the Children's Act 38 of 2005, see Kassan and Mahery Protective Measures 202; Kassan "Trafficking in Children" 1811; HSRC 2010 www.hsrc.ac.za 42.

274 Article 3(a) Palermo Protocol (2000); Kassan and Mahery Protective Measures 202. 
namely debt bondage, forced marriage, child labour and the removal of body parts. $^{275}$

At first glance it seems that the Palermo Protocol and the Children's Act differ also with regard to their scope of application. On the one hand the Palermo Protocol applies to the prosecution of offences established in the protocol, ${ }^{276}$ where those offences are "transnational in nature and involve an organised criminal group". 277 On the other, the Children's Act applies to trafficking "within or across the borders of the Republic". ${ }^{278}$ With the inclusion of these words the act covers not only transnational trafficking in children to and from other countries but also in-country trafficking within the borders of the Republic. ${ }^{279}$ However, it must be borne in mind that the Palermo Protocol has to be interpreted together with the Organized Crime Convention, ${ }^{280}$ which provides that the offence of human trafficking must be established in domestic anti-trafficking legislation without requiring that transnational or organised crime elements be present. $^{281}$ Therefore, although the scope of application seems different, the broader scope of the Children's Act in fact complies with the Palermo Protocol and the Organized Crime Convention.

Apart from creating trafficking offences, chapter 18 of the Children's Act also regulates other matters in regard to trafficking in children, such as the provision of international cooperation ${ }^{282}$ and extraterritorial jurisdiction. ${ }^{283}$ Underpinning the principle of the best interests of the child, the act further provides for the safety of the

275 The Palermo Protocol recognises the removal of "organs" as an example of an exploitative purpose, which is a narrower concept than the removal of "body parts" listed in the Children's Act - SALRC 2008 www.justice.gov.za 13.

276 Article 5 Palermo Protocol (2000).

277 Article 4 Palermo Protocol (2000).

278 Section 1(a) Children's Act 38 of 2005; Bosman-Sadie and Corrie Children's Act 286.

279 Section 1(a) Children's Act 38 of 2005; Kassan "Trafficking in Children" 18-12.

280 Article 1(1) Convention Against Transnational Organised Crime (2000) - Palermo Protocol (2000); see also Kruger Combating Human Trafficking 248.

281 Article 34(2) Convention Against Transnational Organised Crime (2000). A 34(2) of the convention is applicable to the Palermo Protocol, because a 1(3) of the protocol provides that offences established in terms of the protocol must be regarded as offences established in accordance with the convention; see also UNODC 2009 www.unodc.org 14; UNODC 2004 www.unodc.org 258-259, 275-276.

282 Section 283 Children's Act 38 of 2005; Kassan "Trafficking in Children" 18-14, 15; SALRC 2008 www.justice.gov.za 13; Bosman-Sadie and Corrie Children's Act 285-286; HSRC 2010 www.hsrc.ac.za 42.

283 Section 291 Children's Act 38 of 2005; SALRC 2008 www.justice.gov.za 13; Kassan "Trafficking in Children" 18-22; Kassan and Mahery Protective Measures 206; HSRC 2010 www.hsrc.ac.za 43. 
trafficked child and for specific assistance in returning the child to the Republic, ${ }^{284}$ as well as for referral ${ }^{285}$ and repatriation ${ }^{286}$ procedures. However, Kassan ${ }^{287}$ maintains that the provisions for assisting trafficked children in the Children's Act $^{288}$ do not fully comply with all of the types of assistance that states parties are obliged to render or consider in terms of the Palermo Protocol. ${ }^{289}$ Finally, the Children's Act also provides that, when a court has "reason to believe" that parents or persons with parental responsibilities have trafficked a child, their parental responsibilities and rights may be suspended, with the child being placed "in temporary safe care, pending an inquiry by a children's court". 290

The counter-trafficking provisions in the Children's Act make it possible to prosecute offenders for any type of trafficking where a child is the victim. What must be borne in mind, however, is that these provisions remain interim provisions and will be repealed by their incorporation into the proposed counter-trafficking legislation. ${ }^{291}$

\subsection{Criminal Law (Sexual Offences and Related Matters) Amendment Act 32 of 2007}

The Criminal Law (Sexual Offences and Related Matters) Amendment Act 32 of 2007 (Sexual Offences Amendment Act) criminalises sexual abuse or exploitation comprehensively in a single statute. ${ }^{292}$ The act aims to afford complainants involved in sexual offences

the maximum and least traumatising protection that the law can provide ... by establishing a co-operative response between all government departments involved

284 Section 286 Children's Act 38 of 2005; SALRC 2008 www.justice.gov.za 13; Bosman-Sadie and Corrie Children's Act 288-289; HSRC 2010 www.hsrc.ac.za 42.

285 Section 288-289 Children's Act 38 of 2005; Kassan "Trafficking in Children" 18-20; SALRC 2008 www.justice.gov.za 13; Bosman-Sadie and Corrie Children's Act 290-291; HSRC 2010 www.hsrc.ac.za 42-43.

286 Section 290 Children's Act 38 of 2005; Kassan "Trafficking in Children" 18-21; Bosman-Sadie and Corrie Children's Act 291.

287 Kassan "Trafficking in Children" 18-18.

288 Section 286 Children's Act 38 of 2005; HSRC 2010 www.hsrc.ac.za 42.

289 Kassan "Trafficking in Children" 18-18.

290 Section 287 Children's Act 38 of 2005; Kassan "Trafficking in Children" 18-19, 204; BosmanSadie and Corrie Children's Ac t289; HSRC 2010 www.hsrc.ac.za 42-43.

291 SALRC 2006 www.doj.gov.za 3; Kassan "Trafficking in Children" 18-10; Kassan and Mahery Protective Measures 201.

292 Section 2 Criminal Law (Sexual Offences and Related Matters) Amendment Act 32 of 2007; see also Minnie "Sexual Offences" 541-562; HSRC 2010 www.hsrc.ac.za 41. 
in implementing an effective, responsive and sensitive criminal justice system relating to sexual offences. ${ }^{293}$

Pending the adoption of legislation in full compliance with the Palermo Protocol, transitional anti-trafficking provisions were included in the Sexual Offences Amendment Act, which came into operation on 16 December 2007. In partial compliance with South Africa's international counter-trafficking obligations, ${ }^{294}$ this act criminalises conduct constituting trafficking in persons for sexual exploitation. ${ }^{295}$ The act prohibits a person from trafficking any other person, without the consent of that person, for the purpose of sexual exploitation. ${ }^{296}$

The action and means components of the term "trafficking" are defined similarly to those in the Palermo Protocol ${ }^{297}$ and include

the supply, recruitment, procurement, capture, removal, transportation, transfer, harbouring, sale, disposal or receiving of a person, within or across the borders of the Republic, by means of -

(i) a threat of harm;

(ii) the threat or use of force, intimidation or other forms of coercion;

(iii) abduction;

(iv) fraud;

(v) deception or false pretences;

(vi) the abuse of power or of a position of vulnerability, to the extent that the complainant is inhibited from indicating his or her unwillingness or resistance to being trafficked, or unwillingness to participate in such an act; or

(vii) the giving or receiving of payments, compensation, rewards, benefits or any other advantage. ${ }^{298}$

However, the exploitative purpose element in the Sexual Offences Amendment Act fails to comply with the Palermo Protocol, because it provides for an exploitative purpose of a sexual nature only, including

293 Section 2(d) Criminal Law (Sexual Offences and Related Matters) Amendment Act 32 of 2007.

294 Article 5(1) Palermo Protocol (2000); see also s 70(1) Criminal Law (Sexual Offences and Related Matters) Amendment Act 32 of 2007; Minnie "Sexual Offences" 561; HSRC 2010 www.hsrc.ac.za 41.

295 Section 70(1) Criminal Law (Sexual Offences and Related Matters) Amendment Act 32 of 2007.

296 Section 71(1) Criminal Law (Sexual Offences and Related Matters) Amendment Act 32 of 2007: "A person ('A') who traffics any person ('B'), without the consent of $B$, is guilty of the offence of trafficking in persons for sexual purposes." See also Minnie "Sexual Offences" 561; UNODC Global Report 127; HSRC 2010 www.hsrc.ac.za 41.

297 Article 3(1) Palermo Protocol (2000).

298 Section 70(2)(b) Criminal Law (Sexual Offences and Related Matters) Amendment Act 32 of 2007; HSRC 2010 www.hsrc.ac.za 41. 
any form or manner of exploitation, grooming or abuse of a sexual nature of such person, including the commission of any sexual offence or any offence of a sexual nature in any other law against such person or performing any sexual act with such person, whether committed in or outside the borders of the Republic. ${ }^{299}$

The issue of consent in the Sexual Offences Amendment Act is approached differently from that in the Palermo Protocol. The latter provides that consent of the trafficked person is irrelevant where any of the prohibited means have been used or if the trafficked person is a child, who is defined as a person under the age of 18 years. ${ }^{300}$ On the other hand, the Sexual Offences Amendment Act stipulates that "[a] person ("A") who traffics any person ("B"), without the consent of $B$, is guilty of the offence of trafficking in persons for sexual purposes". 301

The act provides that "consent" means voluntary or uncoerced agreement. ${ }^{302}$ Unlike the Palermo Protocol, the act proceeds to list a number of circumstances which would negate valid consent, but stipulates that this is not an exhaustive list of circumstances. ${ }^{303}$ Apart from a number of other circumstances, the means listed in the Palermo Protocol are also included. ${ }^{304}$ The act further provides that children below the age of 12 years are not able to consent validly, because their consent is not regarded as being given "voluntarily or without coercion". ${ }^{305}$ The question that arises is: What then is the position regarding alleged consent by children of age 12 to 17 years? The formulation on this issue in the Sexual Offences Amendment Act differs from the provision in the Palermo Protocol, which does not differentiate

299 Section 70(2)(b) Criminal Law (Sexual Offences and Related Matters) Amendment Act 32 of 2007.

300 Article 3(d) Palermo Protocol (2000).

301 Section 1(1) Criminal Law (Sexual Offences and Related Matters) Amendment Act 32 of 2007; Minnie "Sexual Offences" 561.

302 Section 71(3) Criminal Law (Sexual Offences and Related Matters) Amendment Act 32 of 2007; Minnie "Sexual Offence"s 561-562.

303 Section 71(4) Criminal Law (Sexual Offences and Related Matters) Amendment Act 32 of 2007.

304 Section 71(4) Criminal Law (Sexual Offences and Related Matters) Amendment Act 32 of 2007: "Circumstances in which B does not voluntarily or without coercion agree to being trafficked, as contemplated in subsection (3), include, but are not limited to, the following - (a) where B submits or is subjected to such an act as a result of any one or more of the means or circumstances contemplated in subparagraphs (i) to (vii) of the definition of trafficking having been used or being present; or (b) where B is incapable in law of appreciating the nature of the act, including where $B$ is, at the time of the commission of such act - (i) asleep; (ii) unconscious; (iii) in an altered state of consciousness, including under the influence of any medicine,drug, alcohol or other substance to the extent that B's consciousness or judgement is adversely affected; (iv) a child below the age of 12 years; or (v) a person who is mentally disabled."

305 Section 71(4)(b)(iv) Criminal Law (Sexual Offences and Related Matters) Amendment Act 32 of 2007. 
between children under and over 12 years, but defines a child as any person under the age of 18 years. ${ }^{306}$ Hence, it is submitted that this issue needs to be addressed in the proposed counter-trafficking legislation to bring it in line with the provisions in the Palermo Protocol.

Apart from requiring states parties to criminalise the main crime of human trafficking, the Palermo Protocol further requires the criminalisation of related crimes. The Palermo Protocol's requirement that attempts to commit human trafficking be criminalised is already covered in South African law, since the attempt to commit any crime is recognised as a substantive crime in the South African legal system. ${ }^{307}$ As regards the obligation to prohibit the organising and directing of human trafficking, the Sexual Offences Amendment Act complies with that obligation, but goes further by also prohibiting a person from ordering, commanding, supervising or controlling the trafficking crime. ${ }^{308}$ The act is also more comprehensive than the Palermo Protocol, which criminalises participating "as an accomplice" only in that it criminalises the performance of "any act which is aimed at committing, causing, bringing about, encouraging, promoting, contributing towards or participating in trafficking". 309

A further aspect in respect of which the act is broader than the Palermo Protocol, and one that is to be welcomed, is that the act introduces the crime of involvement in the trafficking of persons in order to bring to book all agents playing a part in the trafficking process. In this regard, the act provides that any person who

incites, instigates, commands, aids, advises, recruits, encourages or procures any other person to commit, cause, bring about, promote, perform, contribute towards or participate in trafficking, is guilty of an offence of involvement in trafficking in persons for sexual purposes. ${ }^{310}$

306 Article 3(d) Palermo Protocol (2000).

307 Attempt to commit a common law crime is in itself a crime under the common law, while $s$ 18(1) of the Riotous Assemblies Act 17 of 1956 criminalises an attempt to commit a statutory offence Burchell Criminal Law 619-641; Snyman Criminal Law 283-294; see also 2.2.1 above.

308 Section 71(2)(a) Criminal Law (Sexual Offences and Related Matters) Amendment Act 32 of 2007; Minnie "Sexual Offences" 561.

309 Section 71(2)(b) Criminal Law (Sexual Offences and Related Matters) Amendment Act 32 of 2007; see also Minnie "Sexual Offences" 561.

310 Section 71(2)(c) Criminal Law (Sexual Offences and Related Matters) Amendment Act 32 of 2007; Minnie "Sexual Offences" 561. 
In view of the fact that transporters often facilitate human trafficking by moving victims illegally across national borders, the act prohibits all "commercial carriers" 111 from bringing a passenger into or removing a person from South Africa without such a passenger having travel documents for the lawful entry into or departure from the Republic of South Africa (the Republic). ${ }^{312}$ This offence overlaps to some extent with the prohibition against assisting another to enter, remain in, or depart from the Republic in contravention of the Immigration Act 13 of 2002 (Immigration Act). ${ }^{313}$ However, the Sexual Offences Amendment Act provides that the transporting offender is also liable for paying the cost of the transported person's care, safekeeping and return from South Africa. ${ }^{314}$

Stuurman ${ }^{315}$ highlights the problem that the victims of human trafficking are often prosecuted. For example, trafficked persons who are in South Africa without valid documentation because their passports have been confiscated by their traffickers may be prosecuted under the Immigration $A c t,{ }^{316}$ while victims forced into prostitution may be prosecuted for prostitution. ${ }^{317}$ The Sexual Offences Amendment Act addresses this issue by stipulating that a victim of trafficking is "not liable for any criminal offence, including any migration-related offence, which was committed as a direct result of being trafficked". ${ }^{318}$

As regards sanctions for trafficking offences established in the Sexual Offences Amendment Act, there is no specific penal provision included in the act. ${ }^{319}$ However,

311 The term "commercial carrier" is defined broadly in s 70(2)(a) to include a company or the owner, operator or master of any means of transport that engages in the transportation of goods or people for commercial gain.

312 Section 71(6)(a) Criminal Law (Sexual Offences and Related Matters) Amendment Act 32 of 2007: "A commercial carrier commits an offence if the carrier brings a person into or removes a person from the Republic and, upon entry into or departure from the Republic, the person does not have the travel documents required for lawful entry into or departure from the Republic." See also Minnie "Sexual Offences" 562; HSRC 2010 www.hsrc.ac.za 41.

313 Section 49(2) Immigration Act 13 of 2002: "Anyone who knowingly assists a person to enter or remain in, or depart from the Republic in contravention of this Act, shall be guilty of an offence and liable on conviction to a fine or to imprisonment not exceeding one year." See also Stuurman 2004 Eye on Human Trafficking 5.

314 Section 71(6)(c) Criminal Law (Sexual Offences and Related Matters) Amendment Act 32 of 2007; see also Minnie "Sexual Offences" 562.

315 Stuurman 2004 Eye on Human Trafficking 5.

316 US Department of State 2011 www.state.gov 330.

317 US Department of State 2011 www.state.gov 330.

318 Section 71(5) Criminal Law (Sexual Offences and Related Matters) Amendment Act 32 of 2007; SOCA Unit 2009 www.info.gov.za 2; HSRC 2010 www.hsrc.ac.za 41.

319 Lotan "Brief Outline" 11. 
the trafficking offences in section 71(1) and (2) of the Sexual Offences Amendment Act are regarded as serious offences, because they are listed in part I of schedule 2 of the Criminal Law Amendment Act 105 of 1997. Accordingly, a court is obliged to impose a minimum sentence of imprisonment for life on offenders convicted of these trafficking offences, ${ }^{320}$ unless the court finds that "substantial and compelling circumstances exist which justify the imposition of a lesser sentence". ${ }^{321}$

\section{Conclusion}

In order to combat human trafficking efficiently and effectively, law enforcement and prosecution officials must keep in mind that human trafficking is a process rather than a single offence:

Trafficking may involve offenses against the state, such as abuse of immigration laws, document forgery, corruption of government officials, money laundering, and tax evasion. Other violations are directed against victims: unlawful coercion or threat, extortion, aggravated assault, sexual assault, rape, or even murder. ${ }^{322}$

Thus, even without comprehensive counter-trafficking legislation, existing common law crimes and statutory offences remain a significant tool to prosecute criminal conduct committed during the trafficking process. ${ }^{323}$ As was pointed out above, ${ }^{324}$ existing provisions have already been applied successfully to obtain convictions for trafficking activities in terms of crimes other than human trafficking. In the case of $S v$ Andrews, the accused was sentenced to 17 years' imprisonment for keeping a brothel in terms of the Sexual Offences Act 23 of 1957 as well as for being an accomplice on two charges of common law rape. ${ }^{325}$ In 2010 , convictions were secured on charges in terms of the Prevention of Organised Crime Act 121 of 1998 and the Immigration Act 13 of 2002 in $S$ v Sayed. ${ }^{326}$ Although the comprehensive

320 Section 51(1) Criminal Law (Sexual Offences and Related Matters) Amendment Act 32 of 2007; HSRC 2010 www.hsrc.ac.za 41.

321 Section 51(3)(a) Criminal Law (Sexual Offences and Related Matters) Amendment Act 32 of 2007.

322 Bales Global Slavery 133.

323 Mnisi "Trafficking in Persons" 2; Kassan "Trafficking in Children" 18-10; SALRC 2008 www. justice.gov.za 14; SOCA Unit 2009 www.info.gov.za 2.

324 See 2.2.7 and 2.2.13 above.

325 S v Andrews (unreported case 27/50/1998; 27 August 2004, Cape Town Regional Court); see also NPA 2010b www.pmg.org.za 11.

326 S v Sayed (unreported case no. 041/2713/2008; 18 March 2010, Durban Regional Court). 
counter-trafficking legislation is not yet in force, traffickers have been convicted in terms of the current transitional trafficking provisions. On 19 July 2011, Aldina Dos Santos was sentenced to life imprisonment in terms of the Criminal Law (Sexual Offences and Related Matters) Amendment Act 32 of 2007 for trafficking three girls from Mozambique to South Africa for sexual exploitation. ${ }^{327}$ Thus, pending the enactment of the all-embracing anti-trafficking legislation, there are numerous existing common law crimes and statutory offences that can be utilised to prosecute offenders for acts committed during the trafficking process. ${ }^{328}$

When the Prevention and Combating of Trafficking in Persons Bill B7 of 2010 comes into force, its extended provisions will indeed open up additional opportunities to prosecute human trafficking more intensively. Still, without duplicating charges the prosecution should, in addition to trafficking offences, charge trafficking agents with all other relevant offences to ensure that human trafficking is met with the full force of the law. For this reason the arsenal of existing crimes and provisions that may be applicable to prosecute traffickers for crimes other than human trafficking remains a significant component in the South African legal response in respect of the combating of human trafficking.

327 The accused was convicted in the Pretoria Regional Court in terms of the Criminal Law (Sexual Offences and Related Matters) Amendment Act 32 of 2007 - SAPA 2011 www.news24.com 1.

328 Mnisi "Trafficking in Persons" 2; Kassan "Trafficking in Children" 18-10; SALRC 2008 www.hsrc.ac.za 14; SOCA Unit 2009 www.info.gov.za 2. 


\section{Bibliography}

Allain 2011 Med L Rev

Allain $\mathrm{J}$ "Trafficking of persons for the removal of organs and the admission of guilt of a South African hospital" 2011 Med L Rev 117-122

Bales Global Slavery

Bales K Understanding Global Slavery (University of California Press Los Angeles 2005)

Bales and Robbins 2001 Human Rights Review

Bales $\mathrm{K}$ and Robbins PT "No one shall be held in slavery or servitude: a critical analysis of international slavery agreements and concepts of slavery" 2001 Human Rights Review 18-45

Bassiouni International Crimes

Bassiouni MC International Crimes: Digest/Index of International Instruments 1815-1985 - Volume 1 (Oceana Publications New York 1986)

Bassiouni 1990/1991 NYUJ Int'l Law \& Pol

Bassiouni MC "Enslavement as an international crime" 1990/1991 NYUJ Int"l Law \& Pol 445-517

Boezaart Child Law

Boezaart T (ed) Child Law in South Africa (Juta Claremont 2009)

Bosman-Sadie and Corrie Children's Act

Bosman-Sadie $\mathrm{H}$ and Corrie $\mathrm{L}$ A Practical Approach to the Children's Act (LexisNexis Durban 2010)

Brennan 2005 International Migration

Brennan D "Methodological challenges in research with trafficked persons: tales from the field" 2005 International Migration 35-48 
Brownlie Public International Law

Brownlie I (ed) Principles of Public International Law 6th ed (Oxford University Press New York 2003)

Brownlie and Goodwin-Gill Human Rights

Brownlie I and Goodwin-Gill GS Basic Documents on Human Rights (Oxford University Press New York 2006)

Burchell Criminal Law

Burchell JM Principles of Criminal Law by J Burchell and J Milton 3rd ed (Juta Lansdowne 2005)

Buys and Cronjé Cyberlaw

Buys R and Cronjé F Cyberlaw@SA II - the Law of the Internet in South Africa 2nd ed (Van Schaik Pretoria 2004)

Currie and De Waal Bill of Rights

Currie I and De Waal J The Bill of Rights Handbook 5th ed (Juta Lansdowne 2005)

David 2007 Trends \& Issues in Crime and Criminal Justice

David F "Law enforcement responses to trafficking in persons: challenges and emerging good practice" 2007 Trends \& Issues in Crime and Criminal Justice 1-6

Dawes, Bray and Van der Merwe Child Well-being

Dawes A, Bray R and Van der Merwe A (eds) Monitoring Child Well-being - a South African Rights-based Approach (HRSC Press Cape Town 2007)

Defeis 2003/2004 ILSA J Int'I \& Comp L

Defeis F "Protocol to Prevent, Suppress and Punish Trafficking in Persons - a new approach" 2003/2004 ILSA J Int'l \& Comp L 485-491 
Devenish Commentary

Devenish GE A Commentary on the South African Constitution (Butterworth Durban 1998)

Devenish Constitution

Devenish GE The South African Constitution (LexisNexis Durban 2005)

Dottridge and Weissbrodt 1999 German Yearbook of International Law

Dottridge $\mathrm{M}$ and Weissbrodt $\mathrm{D}$ "Review of the implementation of and follow-up to the conventions on slavery" 1999 German Yearbook of International Law 242292

Dougherty and Burke 2008 America

Dougherty ME and Burke $\mathrm{J}$ "Exploitation and immigration policy - human bondage" 2008 America (April 142008 Whole No. 4811) 198(12):12-14

Dugard International Law

Dugard J International Law - a South African Perspective 3rd ed (Juta Lansdowne 2005)

Du Plessis Inleiding

Du Plessis L Inleiding tot die Reg 3rd ed (Juta Kenwyn 1999)

Foundation against Trafficking in Women et al Human Rights Standards

Foundation against Trafficking in Women, International Human Rights Law Group and Global Alliance against Traffic in Women Human Rights Standards for the Treatment of Trafficked Persons 3rd ed (Global Alliance against Traffic in Women 2001)

Fritz "Child Slavery/Trafficking"

Fritz E "Child Slavery/Trafficking" (Notes based on the 10th Annual National Child Abuse Conference hosted by the South African Professional Society on the Abuse of Children [SAPSAC] 2009) (Presentation for Students: Life Orientation 
[PGCE-Subject Methodology] on 14 April 2010 at the University of Johannesburg, Johannesburg)

GAATW Human Rights in Practice

Global Alliance against Traffic in Women (GAATW) Human Rights in Practice - a Guide to Assist Trafficked Women and Children (GAATW Bangkok 1999)

Gajic-Veljanoski and Stewart 2007 Trans-cultural Psychiatry

Gajic-Veljanoski $O$ and Stewart DE "Women trafficked into prostitution: determinants, human rights and health needs" 2007 Trans-cultural Psychiatry 338-358

Gastrow Organised Crime

Gastrow P Organised Crime in the SADC Region (ISS Monograph Series No. 60) (Institute for Security Studies Pretoria 2001)

Harrold 2006 Charleston Law Review

Harrold MM "A new kind of traffic(king) cop on the international 'beat' of human trafficking" 2006 Charleston Law Review 98-122

Haynes 2004 Hum Rts Q

Haynes DF "Used, abused, arrested and deported: extending immigration benefits to protect the victims of trafficking and to secure the prosecution of traffickers" 2004 Hum Rts Q 221-272

Hodgkin and Newell Implementation Handbook

Hodgkin $\mathrm{R}$ and Newell $\mathrm{P}$ Implementation Handbook for the Convention on the Rights of the Child (UNICEF New York 2002)

Human "Theory of Children's Rights"

Human S "The Theory of Children's Rights" in Boezaart T (ed) Child Law in South Africa (Juta Claremont 2009) 
Hunt Common Law Crimes

Hunt PMA South African Criminal Law and Procedure - Volume II: Common Law Crimes (Juta Cape Town 1970)

IOM Breaking the Cycle

International Organization for Migration (IOM) Breaking the Cycle of Vulnerability: Responding to the Health Needs of Trafficked Women in East and Southern Africa (IOM Pretoria 2006)

IOM Counter-trafficking

International Organization for Migration (IOM) Handbook on Counter-trafficking for South African Government and Civil Society Stakeholders (IOM Pretoria 2009)

IOM Training of Trainers

International Organization for Migration (IOM) Training of Trainers on Combating Human Trafficking for South African Civil Society Organisations (IOM Pretoria 2007)

Kamidi Legal Response to Child Trafficking

Kamidi R A Legal Response to Child Trafficking in Africa: a Case Study of South Africa and Benin (LLM dissertation UWC 2007)

Kanics and Reiter 2001 Helsinki Monitor

Kanics J and Reiter G "2000: a year of significant achievements in the fight against trafficking in human beings" 2001 Helsinki Monitor 12(2):112-121

Kassan "Trafficking in Children"

Kassan D "Trafficking in Children" in Davel CJ and Skelton AM Commentary on the Children's Act (Juta Cape Town 2007) 
Kassan and Mahery "Protective Measures"

Kassan D and Mahery P "Special Child Protective Measures in the Children's Act" in Boezaart T Child Law in South Africa (Juta Claremont 2009)

Kleyn and Viljoen Beginner's Guide

Kleyn D and Viljoen F Beginner's Guide for Law Students 3rd ed (Juta Law Lansdowne 2002)

Koyana and Bekker 2007 De Jure

Koyana DS and Bekker JC "The indomitable ukuthwala custom" 2007 De Jure 40(1):139-144

Kreston 2007 Child Abuse Research in South Africa

Kreston SS "Trafficking in children in South Africa: an analysis of pending legislation" 2007 Child Abuse Research in South Africa 35-50

Kruger Combating Human Trafficking

Kruger HB Combating Human Trafficking: a South African Legal Perspective (LLD thesis UFS 2010)

Kruger Organised Crime

Kruger A Organised Crime and Proceeds of Crime Law in South Africa (LexisNexis Durban 2008)

Lansdown, Hoal and Lansdown Specific Offences

Lansdown CWH, Hoal WL and Lansdown AV Gardner and Lansdown South African Criminal Law and Procedure: Volume II Specific Offences 6th ed (Juta Cape Town 1957)

Lansink 2006 Agenda

Lansink $A$ "Human rights focus on trafficked women: an international law and feminist perspective" 2006 Agenda 70:45-56 


\section{Lee Human Trafficking}

Lee L Human Trafficking (William Publishing Devon 2007)

Lotan "Brief Outline"

Lotan V "Brief Outline of Human Trafficking: Thai Cases No 1 and 2" (Unpublished contribution delivered at Tsireledzani: Towards an Integrated Human Trafficking National Action Plan Conference 25-27 March 2009 Durban)

McClain 2007 Vanderbilt J Transnat'I L

McClain TR "An ounce of prevention: improving the preventative measures of the Trafficking Victims Protection Act' 2007 Vanderbilt J Transnat'l L 580-607

McQuoid-Mason 2009 Obiter

McQuoid-Mason D "The practice of 'ukuthwala', the Constitution and the Criminal Law (Sexual Offences and Related Matters) Amendment Act" 2009 Obiter 716723

Melvin Human Trafficking

Melvin JL Human Trafficking: a Theoretical Application of Anomie on the Tier Placement System Utilized by the U.S. Department of State's "Trafficking in Persons" Report (Master's Dissertation Grand Valley State University 2006)

\section{Milton Common Law Crimes}

Milton JRL South African Criminal Law and Procedure - Volume II: Common Law Crimes 3rd ed (Juta Kenwyn 1996)

Minnie "Sexual Offences"

Minnie D "Sexual Offences against Children" in Boezaart T Child Law in South Africa (Juta Claremont 2009)

Mnisi "Trafficking in Persons"

Mnisi J "Trafficking in Persons - Current Legal Framework in South Africa" (Unpublished contribution delivered at Training Workshop on Human Trafficking hosted by the National Prosecuting Authority 6-8 October 2008 Bloemfontein) 
Molo Songololo Trafficking in Children

Molo Songololo Trafficking in Children for the Purposes of Sexual Exploitation South Africa (Molo Songololo Cape Town 2000)

Morawska "Trafficking"

Morawska E "Trafficking into and from Eastern Europe" in Lee M Human Trafficking (Willan Publishing Devon 2007)

Mwambene and Sloth-Nielsen 2011 African Human Rights Law Journal

Mwambene L \& Sloth-Nielsen J "Benign accommodation? Ukuthwala, 'forced marriage' and the South African Children's Act' 2011 African Human Rights Law Journal 1-22

Ncube "Possible Contribution"

Ncube $\mathrm{J}$ "Possible Contribution of SADC Secretariat to Prevent and Respond to Human Trafficking, Labour and Sexual Exploitation of Children in Southern Africa" (Unpublished contribution delivered at Regional Conference on Prevention and Intervention Against Child Trafficking hosted by the Southern Africa Network Against Trafficking and Abuse of Children [SANTAC] 8-9 October 2008 Maputo)

Nowak Civil and Political Rights

Nowak M U.N. Covenant on Civil and Political Rights - CCPR Commentary 2nd ed (NP Engel Kehl 2005)

Obokata Trafficking of Human Beings

Obokata T Trafficking of Human Beings from a Human Rights Perspective: towards a Holistic Approach (Martinus Nijhoff Publishers Leiden 2006)

Olivier et al Indigenous Law

Olivier NJJ et al Indigenous Law (Butterworths Durban 1995) 
Picarelli "Historical Approaches"

Picarelli JT "Historical Approaches to the Trade in Human Beings" in Lee M Human Trafficking (Willan Publishing Devon 2007)

Planitzer Counter-trafficking Cooperation

Planitzer J Guiding Principles on Memoranda of Understanding between Key Stakeholders and Law Enforcement Agencies on Counter-trafficking Cooperation (IOM Vienna 2009)

Raymond 2002 Women's International Forum

Raymond JG "The new UN trafficking protocol" 2002 Women's International Forum 491-502

Rijken Trafficking in Persons

Rijken C Trafficking in Persons: Prosecution from a European Perspective (TMC Asser Press The Hague 2003)

Shelley "Human Trafficking"

Shelley $L$ "Human Trafficking as a Form of Transnational Crime" in Lee $M$ Human Trafficking (Willan Publishing Devon 2007)

Singh 2004 CILSA

Singh D "Piercing the veil on trafficking in women" 2004 CILSA 340-373

Slabbert 2009 Obiter

Slabbert $M$ "This is my kidney, I can do what I want with it - property rights and ownership of human organs" 2009 Obiter 499-517

Smith "South Africa's Strategy"

Smith P "South Africa's Strategy to Address Human Trafficking in Persons" (Unpublished contribution delivered at Regional Conference on Prevention and Intervention against Child Trafficking hosted by the Southern Africa Network Against Trafficking and Abuse of Children [SANTAC] 8-9 October 2008 Maputo) 


\section{Snyman Criminal Law}

Snyman CR Criminal Law 5th ed (LexisNexis Durban 2008)

Snyman "Victims"

Snyman R "Victims of Human Trafficking" in Davis L and Snyman R Victimology in South Africa (Van Schaik Pretoria 2005)

Stuurman 2004 Eye on Human Trafficking

Stuurman L "Anti-trafficking legislation can no longer be delayed" 2004 Eye on Human Trafficking 3:5

UN.GIFT "Demand for Forced Labour"

United Nations Global Initiative to Fight Human Trafficking (UN.GIFT) "Demand for Forced Labour and Sexual Exploitation - How and Why It Fuels Human Trafficking" (Background Paper 004 Workshop [UN.GIFT B.P.:004] delivered at The Vienna Forum to Fight Human Trafficking 13-15 February 2008 Vienna)

UN.GIFT "Human Trafficking" United Nations Global Initiative to Fight Human Trafficking (UN.GIFT) "Human Trafficking for the Removal of Organs and Body Parts" (Background Paper 011 Workshop [UN.GIFT B.P.:011] delivered at The Vienna Forum to Fight Human Trafficking 13-15 February 2008 Vienna)

UN.GIFT "Profiling the Traffickers" United Nations Global Initiative to Fight Human Trafficking (UN.GIFT) "Profiling the Traffickers" (Background Paper 016 Workshop [UN.GIFT B.P.:016] delivered at The Vienna Forum to Fight Human Trafficking 13-15 February 2008 Vienna)

\section{UNODC Toolkit}

United Nations Office on Drugs and Crime (UNODC) Toolkit to Combat Trafficking in Persons - Global Programme against Trafficking in Human Beings (United Nations New York 2006) 
UNODC Global Report

United Nations Office on Drugs and Crime (UNODC) Global Report on Trafficking in Persons (UNODC Vienna 2009)

Viljoen Human Rights Law

Viljoen F International Human Rights Law in Africa (Oxford University Press New York 2007)

Weissbrodt and Anti-slavery International Abolishing Slavery

Weissbrodt D and Anti-slavery International Abolishing Slavery and Its Contemporary Forms (Report for the Office of the United Nations High Commissioner for Human Rights HR/PUB/02/4) (United Nations New York 2002)

\section{Register of legislation}

Basic Conditions of Employment Act 75 of 1997

Child Care Act 74 of 1983

Children's Act 38 of 2005

Constitution of the Republic of South Africa, 1996

Criminal Law (Sexual Offences and Related Matters) Amendment Act 32 of 2007

Drugs and Drug Trafficking Act 140 of 1992

Films and Publications Act 65 of 1996

General Law Amendment Act 139 of 1992

Human Tissue Act 65 of 1983

Identification Act 68 of 1997

Immigration Act 13 of 2002

International Co-operation in Criminal Matters Act 75 of 1996

National Health Act 61 of 2003

Prevention and Combating of Corrupt Activities Act 12 of 2004

Prevention of Organised Crime Act 121 of 1998

Riotous Assemblies Act 17 of 1956

Sexual Offences Act 23 of 1957

Prevention and Combating of Trafficking in Persons Bill B7-2010 


\section{Register of government publications}

Proc R19 in GG 27503 of 18 April 2005

Proc R20 in GG 33187 of 14 May 2010

\section{Register of international instruments}

Convention Against Transnational Organized Crime (2000)

Palermo Protocol (Protocol to Prevent, Suppress and Punish Trafficking in Persons, Especially Women and Children) (2000)

International Labour Organization Convention (No. 29) Concerning Forced Labour (1930)

Universal Declaration of Human Rights (1948)

\section{Register of case law}

Green v Fitzgerald 1914 AD 88

National Director of Public Prosecutions v Geyser 20082 SACR (SCA) 103

National Director of Public Prosecutions v RO Cook Properties (Pty) Ltd; National Director of Public Prosecutions v 37 Gillespie Street Durban (Pty) Ltd; National Director of Public Prosecutions v Seevnarayan 20042 SACR 208 (SCA) NDPP v Mohamed 20022 SACR 196 (CC)

$R v$ Hanson 18492 C \& K 912

$R v$ Holliday 1927 CPD 395

$S \vee$ Andrews (unreported case no. 27/50/1998; 27 August 2004, Cape Town Regional Court)

$S$ v De Vries 20091 SACR 613 (C)

$S$ v Dos Santos (unreported case; 19 July 2011, Pretoria Regional Court)

$S$ v Eloff (unreported case no. SH599/08; Welkom)

$S$ v Mudaly (pending case no. 41/890/2007; Durban Regional Court)

$S$ v Netcare Kwa-Zulu (Proprietary) Limited (unreported case no. 41/1804/2010; 8

November 2010, Durban Regional Court)

$S$ v Nyalungu 2005 JOL $13254 \mathrm{~T}$

$S$ v Sawatkan (unreported case no. 41/2045/08; Durban) 
S v Sayed (unreported case no. 041/2713/2008; 18 March 2010, Durban Regional Court)

$S$ v Wiphatawaithaya (unreported case no. 317/2/09; Durban)

\section{Register of Internet sources}

Fellows 2008 www.scribd.com

Fellows S 2008 Trafficking Body Parts in Mozambique and South Africa http://www.scribd.com/doc/23729111/Trafficking-Body-Parts-in-Mozambiqueand-South-Africa-Mozambique-Human-Rights-League [date of use 21 Sep 2010]

HSRC 2010 www.hsrc.ac.za

Human Sciences Research Council (HSRC) 2010 Tsireledzani: Understanding the Dimensions of Human Trafficking in South Africa http://www.hsrc.ac.za/Document-3562.phtml [date of use 25 Mar 2010]

International Crime and Terrorism 2004 www.dfait-maeci.gc.ca

International Crime and Terrorism 2004 Human Trafficking and Migrant Smuggling http://www.dfait-maeci.gc.ca/internationalcrime/human_traffickingen.asp [date of use 30 Nov 2006]

IOM 2008 iom.org.za

International Organization for Migration (IOM) 2008 No Experience Necessary: The Internal Trafficking of Persons in South Africa http://iom.org.za/site/index.php?option=com_docman\&task=doc_details\&gid=12 3ltemid=50 [date of use 4 Nov 2008]

Jordan 2002 www.walnet.org

Jordan AD 2002 The Annotated Guide to the Complete UN Trafficking Protocol (Compiled for the International Human Rights Law Group) http://www.walnet.org/csis/papers/UN-TRAFFICK.PDF [date of use 13 Nov 2008] 
NPA 2010a www.pmg.org.za

National Prosecuting Authority (NPA) 2010 National Prosecuting Authority: Human Trafficking Statistics and Case Analysis - Presentation to the Justice and Constitutional Development Portfolio Committee on 16 November 2010 http://www.pmg.org.za/files/docs/101116npa.pdf [date of use 24 Nov 2010]

NPA 2010b www.pmg.org.za

National Prosecuting Authority (NPA) 2010 National Prosecuting Authority Statistics November 2010 - Adv A van der Byl http://www.pmg.org.za/files/docs /101117npa.ppt [date of use 24 Nov 2010]

NPA 2010c www.pmg.org.za

National Prosecuting Authority (NPA) 2010 National Prosecuting Authority: Statistics on Human Trafficking Cases - Presentation to the Justice and Constitutional Development Portfolio Committee on 16 November 2010 http://www.pmg.org.za/files/docs/101116NPAStats.xls [date of use 16 Nov 2010]

Parliamentary Committee on Justice and Constitutional Development 2010 www.pmg.org.za

Parliamentary Committee on Justice and Constitutional Development 2010 Prevention and Combating of Trafficking in Persons Bill (B7-2010): Department's Response to Submissions - Minutes of Meeting of Portfolio Committee on Justice and Constitutional Development, 15 September 2010 http://www.pmg.org.za/print/23387 [date of use 24 Nov 2010]

SALRC 2004 www.doj.gov.za

South African Law Reform Commission (SALRC) 2004 Trafficking in Persons. Project 131 (Issue Paper 25) http://www.doj.gov.za/salrc/ipapers/ip25_prj 131_2004.pdf [date of use 11 Mar 2008] 
SALRC 2006 www.doj.gov.za

South African Law Reform Commission (SALRC) 2006 Trafficking in Persons. Project 131 (Discussion Paper 111) http://www.doj.gov.za/salrc/dpapers.htm [date of use 11 Mar 2008]

SALRC 2008 www.justice.gov.za

South African Law Reform Commission (SALRC) 2008 Report on Trafficking in Persons. Project 131 http://www.justice.gov.za/salrc/reports/r_pr131_ trafficking_2008.pdf [date of use 23 Mar 2008]

SAPA 2011 www.news24.com

SAPA 2011 'Human Trafficker Gets Life Sentence' News24 20 July 20111 http://www.news24.com/printArticle.aspx?iframe\&aid=bdbc90ea-5794-403c95df-e7 [date of use 21 Jul 2011]

SOCA Unit 2009 www.info.gov.za

SOCA Unit (NPA) (Sexual Offences and Community Affairs Unit in National Prosecuting Authority) 2009 Tsireledzani - Prevent, Respond and Support http://www.info.gov.za/issues/humantrafficking/documents/tsireledzani.pdf [date of use 4 Mar 2010]

The Future Group 2007 tfgwebmaster.web.aplu.net

The Future Group 2007 Human Trafficking - a Human Security Crisis of Global Proportions http://tfgwebmaster.web.aplu.net/wwwthefuturegrouporg/id20.html [date of use 20 Aug 2008]

UN General Assembly 2000 www.unodc.org

UN General Assembly 2000 Addendum: Interpretative Notes for the Official Records (Travaux Préparatoires) of the Negotiation of the Protocol to Prevent, Suppress and Punish Trafficking in Persons, especially Women and Children, Supplementing the United Nations Convention Against Transnational Organized Crime. A/55/383/Add.1 http://www.unodc.org/pdf/ctoccop_2006/0460074_ebook-e.pdf [date of use 18 Nov 2008] 
UNODC 2004 www.unodc.org

United Nations Office on Drugs and Crime (UNODC) 2004 Legislative Guides for the Implementation of the United Nations Convention against Transnational Organized Crime and the Protocols Thereto http://www.unodc.org/unodc/en /treaties/CTOC/legislative-guide.html [date of use 17 Aug 2010]

UNODC 2008 www.unodc.org

United Nations Office on Drugs and Crime (UNODC) 2008 Toolkit to Combat Trafficking in Persons - Global Programme Against Trafficking in Human Beings. New York: United Nations http://www.unodc.org/documents /human-trafficking/HT_Toolkit08_English.pdf [date of use 16 Oct 2008]

UNODC 2009 www.unodc.org

United Nations Office on Drugs and Crime (UNODC) 2009 Model Law for Trafficking in Persons http://www.unodc.org/documents/human-trafficking/ Model_Law_against_TIP.Pdf [date of use_14 Jul 2010]

US Department of State 2007 www.state.gov

United States of America Department of State (US Department of State) 2007 Trafficking in Persons Report http://www.state.gov/g/tip/rls/tiprpt/2007 [date of use 22 Jul 2007]

US Department of State 2008 www.state.gov

United States of America Department of State (US Department of State) 2008 Trafficking in Persons Report http://www.state.gov/g/tip/rls/tiprpt/2008 [date of use 1 Aug 2008]

US Department of State 2009 www.state.gov

United States of America Department of State (US Department of State) 2009 Trafficking in Persons Report http://www.state.gov/documents/organization 1123357.pdf [date of use 30 Jun 2009] 
US Department of State 2010 www.state.gov

United States of America Department of State (US Department of State) 2010 Trafficking in Persons Report http://www.state.gov/documents /organization/142979.pdf [date of use 18 Jun 2010]

US Department of State 2011 www.state.gov

United States of America Department of State (US Department of State) 2011 Trafficking in Persons Report http://www.state.gov/g/tip/rls/tiprpt/2011 [date of use 15 Jul 2011]

Zimmerman et al 2006 www.Ishtm.ac.uk

Zimmerman C et al 2006 Stolen Smiles: a Summary Report on the Physical and Psychological Health Consequences of Women and Adolescents Trafficked in Europe (Report for the London School of Hygiene \& Tropical Medicine, London) http://www.Ishtm.ac.uk/genderviolence [date of use 14 Jul 2008]

\section{List of abbreviations}

CILSA

Hum Rts Q

ILSA J Int'I \& Comp L

Med L Rev

NYUJ Int'l Law \& Pol

Trafficking Protocol

UNCTOC

Vanderbilt J Transnat'I L
Comparative and International Law Journal of Southern Africa Human Rights Quarterly ILSA Journal of International \& Comparative Law Medical Law Review

New York University Journal of International Law and Politics

Protocol to Prevent, Suppress and Punish Trafficking in Persons, Especially Women and Children, supplementing the United Nations Convention against Transnational Organized Crime Convention Against Transnational Organized Crime Vanderbilt Journal of Transnational Law 